Discussion Paper No. 11-055

An Information Economics Perspective on Main Bank Relationships and Firm R\&D

Daniel Hoewer, Tobias Schmidt, and Wolfgang Sofka

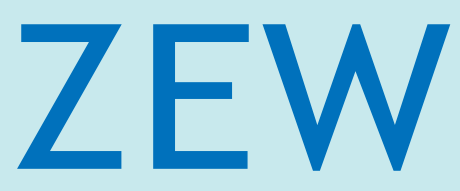

Zentrum für Europäische Wirtschaftsforschung $\mathrm{GmbH}$ Centre for European Economic Research 
Discussion Paper No. 11-055

\title{
An Information Economics Perspective on Main Bank Relationships and Firm R\&D
}

\author{
Daniel Hoewer, Tobias Schmidt, \\ and Wolfgang Sofka
}

Download this ZEW Discussion Paper from our ftp server:

http://ftp.zew.de/pub/zew-docs/dp/dp11055 .pdf

Die Discussion Papers dienen einer möglichst schnellen Verbreitung von neueren Forschungsarbeiten des ZEW. Die Beiträge liegen in alleiniger Verantwortung der Autoren und stellen nicht notwendigerweise die Meinung des ZEW dar.

Discussion Papers are intended to make results of ZEW research promptly available to other economists in order to encourage discussion and suggestions for revisions. The authors are solely responsible for the contents which do not necessarily represent the opinion of the ZEW. 


\section{Non Technical Summary}

The continuous generation of innovative products, processes and services is widely considered to be the primary key to firms' competitiveness and growth. The major input in this innovation process is unique knowledge generated by investments in research and development (R\&D). Interestingly enough, though, private firms have found it extremely difficult to obtain external capital for funding such crucial investments into their future. Banks as the main provider of external funds for the vast majority of firms seem ill-equipped to provide the necessary funding. Their shortcomings are typically explained by the nature of R\&D projects, which suffer from both information imperfections and asymmetries.

We adopt a novel perspective by challenging the dominant assumption that all banks are equally subject to suffering from information asymmetries in financing private R\&D. We suggest that firms can signal the value of their R\&D investment and overcome the inherent information asymmetries. We focus on two mechanisms for signaling. On the one hand, firms can signal based on past innovation success. We will rely on firm's patent stock to measure this. On the other hand, firms can signal based on relations with trusted external actors such as a joint venture investor or the government (through a subsidy). We consider all of these mechanisms and allow for heterogeneities across industries and banks in the valuation of the signals.

We test this theoretical framework empirically for more than 7,000 firm observations on R\&D investments in Germany between 2002 and 2006. Unique access to the database of Germany's leading credit rating agency on the population of German firms and their main bank relationship allows us to construct novel variables on the overall portfolio of the firm's main bank. We have the rare opportunity to link this information to firm characteristics, $R \& D$ investment, patent statistics and venture capital investments based on a non-heuristic link.

The empirical results corroborate our theoretical model only for the signaling value of firm's patent stock. Firms can shift the threshold of a bank's risk considerations to lower levels of specialization if they can signal the value of their R\&D activities through successful patent activities. On the basis of these findings, implications are derived for academic research, management and policy making. 


\section{Nicht technische Zusammenfassung}

Kontinuierliche Innovationsaktivitäten werden weithin als wichtige Voraussetzung für die Wettbewerbsfähigkeit und das Wachstum von Unternehmen angesehen. Der wichtigste Input in den Innovationsprozess ist spezifisches und neues Wissen, das durch Investitionen in Forschung und Entwicklung (FuE) entsteht. Allerdings ist es für private Unternehmen äußerst schwierig, sich externe Finanzierungsmöglichkeiten für diese Art von Zukunftsinvestitionen zu erschließen. Insbesondere Banken, die für die Mehrzahl der Unternehmen die bedeutendste Quelle für externe Finanzierung sind, scheinen nur bedingt in der Lage zu sein, FuE zu finanzieren. Dies wird typischerweise mit der Natur von FuE-Aktivitäten erklärt, weil dabei große Informationsasymmetrien zwischen Unternehmen und externen Investoren entstehen.

In dieser Arbeit stellen wir die allgemeine Annahme, dass alle Banken gleichermaßen von diesen Informationsasymmetrien betroffen sind, in Frage. Wir gehen davon aus, dass Unternehmen Informationsasymmetrien reduzieren können, indem sie den Wert ihrer FuE Aktivitäten den potentiellen Investoren signalisieren. Mindestens zwei unterschiedlich Signale sind denkbar: erstens, in der Vergangenheit erfolgreich abgeschlossene FuE-Projekte oder Patente und zweitens, Kooperationen und Partnerschaften mit externen Akteuren, wie z.B. VC-Gebern oder Ministerien. Wir betrachten in dieser Arbeit beide Signale und lassen zu, dass deren Wirkung und Stärke von Bank zu Bank und Branche zu Branche unterschiedlich ist.

Wir testen unsere Hypothesen für einen Datensatz mit mehr als 7000 Unternehmen mit Sitz in Deutschland. Der Mikrodatensatz deckt die Jahre 2002 bis 2006 ab und enthält neben Daten zu allgemeinen Firmencharakteristika sowohl Informationen zu den FuE Ausgaben der Unternehmen als auch zur Portfoliozusammensetzung der wichtigsten Bank, mit der das Unternehmen zusammenarbeitet. Wir sind in der Lage, diese Informationen, direkt mit Daten zu Patenten, öffentlicher Förderung und Venture Capital Beteiligungen zu ergänzen.

Die empirischen Ergebnisse bestätigen unsere Hypothesen nur bezüglich der Signalwirkung von Patenten. Die Unternehmen können die Risikoeinschätzungen der Banken positiv beeinflussen, wenn sie ihre Forschungsstärke durch Patente untermauern. Des Weiteren zeigen wir, dass die Reduktion von Informationsasymmetrien insbesondere in Sektoren auftritt, in denen große Unsicherheit hinsichtlich der Kommerzialisierbarkeit von FuE besteht. 


\title{
An Information Economics Perspective on Main Bank Relationships and Firm R\&D
}

\author{
Daniel Hoewer, Tobias Schmidt, Wolfgang Sofka
}

August 2011

\begin{abstract}
:
Information economics has emerged as the primary theoretical lens for framing financing decisions in firm R\&D investment. Successful outcomes of R\&D projects are either ex-ante impossible to predict or the information is asymmetrically distributed between inventors and investors. As a result, bank lending for firm R\&D has been rare. However, firms can signal the value of their $R \& D$ activities and as a result reduce the information deficits that block the availability of external funding. In this study we focus on three types of signals: Firm's existing patent stock, the presences of a joint venture investor and whether the firm has received a government $R \& D$ subsidy. We argue theoretically that all of these signals have the potential to alter the risk assessment of the firm's main bank. Additionally, we explore heterogeneities in these risk assessments arising from the industry level and the main bank's portfolio. We test our theoretical predictions for a sample of more than 7,000 firm observations in Germany over a multi-year period. Our theoretical predictions are only supported for firms' past patent activity while other signals fail to alter the risk assessment of a firm's main bank. Besides, we confirm that the risk evaluation is not randomly distributed across bank-firm dyads but depends on industry and bank characteristics.
\end{abstract}

Keywords: innovation, banking, information asymmetry

JEL-Classification: 032, D82, G30

Acknoledgements:

The authors wish to thank Heinz Herrmann, Xavier Martin, Thijs Peeters and Zilin He for their excellent feedback and comments.

\section{Adresses:}

Daniel Höwer, ZEW Centre for European Economic Research, L 7, 1, 68161 Mannheim, Germany, hoewer@zew.de, Telephone: +49 6211235187.

Tobias Schmidt, Deutsche Bundesbank, Economic Research Centre, Wilhelm-Epstein-Strasse 14, 60431 Frankfurt am Main, Germany, tobias.schmidt@bundesbank.de, Telephone: +49 6995663730.

Wolfgang Sofka, Department of Organisation and Strategy, CentER, CIR, Tilburg University, Warandelaan 2, 5000LE Tilburg, the Netherlands, W.E.J.Sofka@uvt.nl, Telephone: +31 134664051. 


\section{Contents}

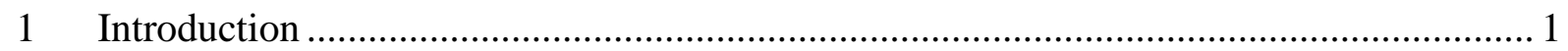

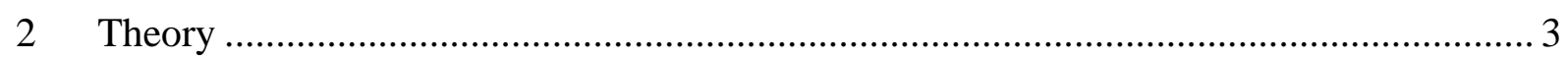

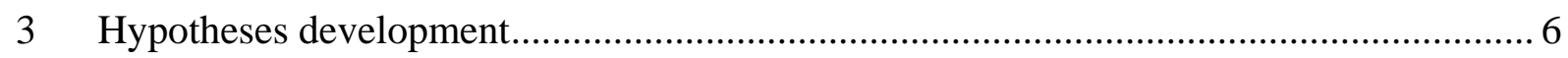

3.1 Information externalities from a firm's main bank client portfolio ........................... 6

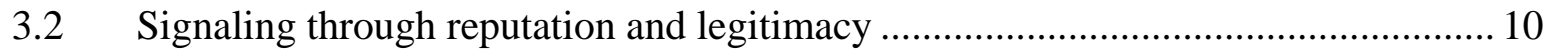

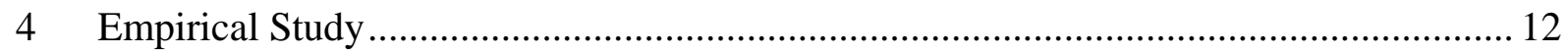

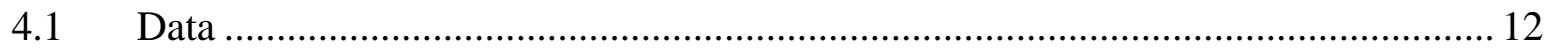

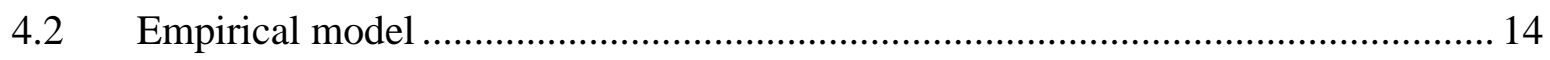

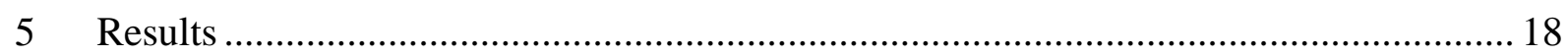

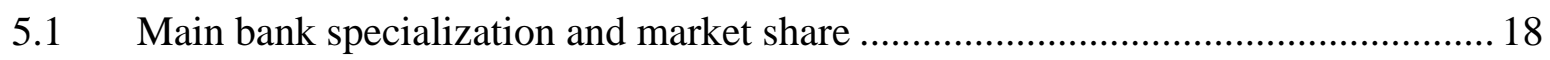

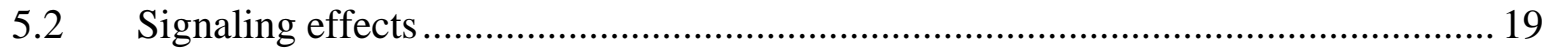

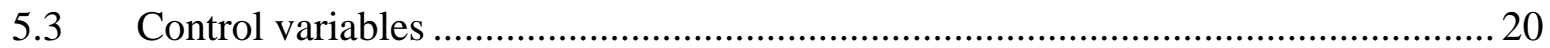

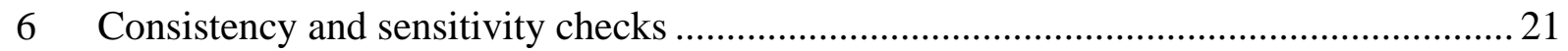

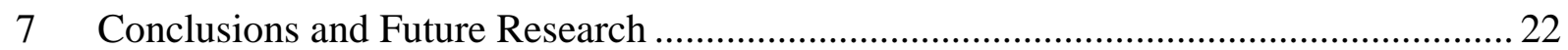

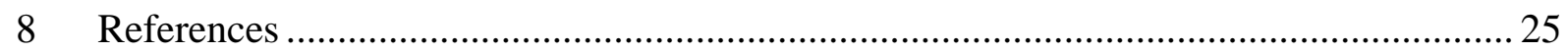

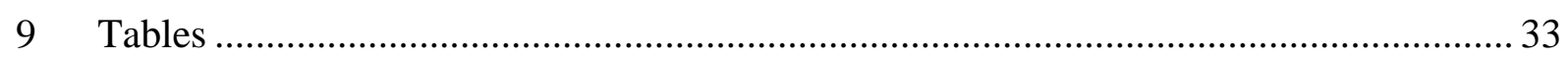

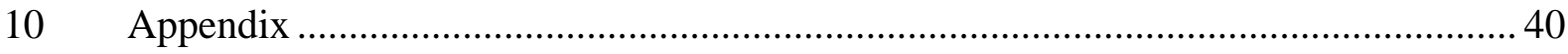

\section{List of Tables}

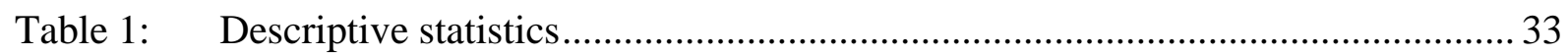

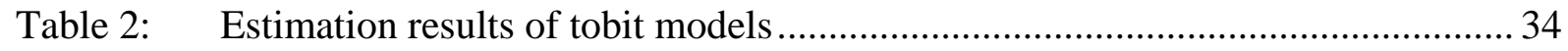

Table 3: Estimation results of tobit models with sub-samples of above/below average industry use of scientific knowledge .............................................................. 36

Table 4: Estimation results of tobit models including interaction effects ......................... 38 


\section{An Information Economics Perspective on Main Bank Relationships and Firm R\&D}

\section{$1 \quad$ Introduction}

The continuous generation of innovative products, processes and services is widely considered to be the primary key to the competitiveness and growth of firms and of entire economies (e.g. Grant, 1996; Schumpeter, 1942). The major input of this innovation process is unique knowledge generated by investments in research and development. Interestingly enough, though, private firms have found it extremely difficult to obtain external capital for funding these crucial investments into their future. This restricts the available funds to internal cash flows and scarce, highly selective venture capital investors (e.g. Levitas \& McFadyen, 2009). For example, Bureau van Dijk’s ZEPHYER database records a yearly average of only 250 venture capital investments in Germany between 1998 and 2010, the fourth largest economy in the world with a population of roughly 3.1 million firms.

This situation is paradoxical as most managers and management research acknowledges the importance of knowledge production and innovation for firm performance (e.g. Grant, 1996; Leiponen \& Helfat, 2010). Entire economies are searching for strategies for entering the knowledge-based economy and reaping the benefits in terms of investment, employment and growth. Among the most ambitious of these plans are the Barcelona and Lisbon Strategies with their aim of making the European Union the most competitive knowledge-based economy in the world. In reality, though, the knowledge-based economy finds itself without a mechanism for financing the underlying firm R\&D investment. Several scholars have highlighted the need for banks - as the main provider of external financing - to be brought back into the picture. The relevance of this topic is acknowledged in the US, for instance, by Nobel laureate Edmund Phelps (Phelps \& Tilman, 2010), and in Europe (e.g. Peutz, Meeus, Nooteboom \& Noorderhaven, 2010).

These shortcomings in capital markets are typically explained by the nature of $R \& D$ projects, which suffer both from information imperfections and asymmetries (for a comprehensive review see Hall, 2005). Information imperfections stem from inherent uncertainties about the technological and commercial viability of novel products for which no 
ex ante probabilities of success exist (Amit, Glosten \& Muller, 1990). Information asymmetries arise from the fact that firms possess knowledge of the value of their $R \& D$ projects which is superior to that of external investors (Ahuja, Coff \& Lee, 2005). These investors, therefore, bear the extra risk of hidden information and hidden actions.

We develop theory based on the renewed interest in financing $R \& D$ and innovation in both from strategic management (e.g. Levitas \& McFadyen, 2009) and finance literature (e.g. Herrera \& Minetti, 2007; Benfratello, Schiantarelli \& Sembenelli, 2008). We adopt a novel perspective based on information economics theory by challenging the dominant assumption that all banks are equally subject to suffering from information asymmetries in financing private $R \& D$ projects. We acknowledge that banks cannot produce the relevant information on technological innovation themselves, although they are uniquely positioned to aggregate the outcomes of the information production of other firms in the industry in the client portfolio, i.e. there exist information externalities (Stiglitz, 2002) originating from heterogeneous client portfolios of different banks. We contrast this perspective by relying on portfolio theory which posits the opposite relationship: Correlated risks in specialized bank portfolios should make R\&D investment in client firms less likely (Markowitz, 1991). Finally, we allow for a proactive role of firms in signaling the value of their $R \& D$ activities to banks through patenting, obtaining government R\&D subsidies or venture capital investment.

We test this theoretical framework empirically for more than 7,000 firm observations on R\&D investments in Germany between 2002 and 2006. Unique access to the database of Germany's leading credit rating agency on the population of German firms and their main bank relationship allows us to construct novel variables on the overall portfolio of each of the firms' main bank. We have the rare opportunity to link this information to firm characteristics, R\&D investment, patent statistics and venture capital investments based on a direct, non-heuristic link. In terms of industry, firm and variable coverage, the dataset is, to the best of our knowledge, unique in its breadth and representativeness.

The empirical results corroborate our theoretical model. Firm R\&D investment is higher if its main bank is either highly diversified or very active in its particular industry. The information externality effect is restricted to sectors in which ther are major uncertainties about commercial application. Firms can shift the threshold of a bank's risk considerations to lower levels of specialization if they can signal the value of their $R \& D$ activities through 
successful patent activities. Successful applications for government R\&D subsidies and venture capital investment, though, are valuable in themselves for firm $R \& D$ investment but fail to alter bank risk assessments significantly. On the basis of these findings, implications are derived for academic research, management and policy making.

The remainder of the article is structured as follows. Section 2, following this introduction, outlines our theoretical framework culminating in the derivation of hypotheses in section 3. In section 4 we present our empirical study including data, variables and methodologies. Section 5 presents the results of these analyses followed by derived conclusions in section 6 .

\section{Theory}

We choose information economics and related signaling theory as our main theoretical building blocks (e.g. Stiglitz, 2002; Ahuja et al., 2005). We shall focus more precisely on signaling theory's relevance to bank financing of private R\&D activities. To achieve this we combine research from finance literature on bank lending decisions (e.g. Rajan \& Zingales, 2001) with the literature on knowledge production through $R \& D$. We start by modeling the R\&D investment decision of any given firm:

R\&D (Industry characteristics, existing knowledge, funds)

A firm's R\&D investment decisions can be described as a function of the characteristics of its industry, its existing knowledge, and the available funds. This study will focus on available funds, while industry characteristics and knowledge are largely treated as control variables ${ }^{1}$. We conceptualize a firm's available funds as a general liquidity pool from which a firm can draw financial resources for its $R \& D$ investment. We explicitly acknowledge that $R \& D$ investment competes with other firm functions (e.g. marketing) for these funds. The pool of available funds determines the cost of capital for a company. Firms will invest in projects

\footnotetext{
${ }^{1}$ Important industry characteristics encompass the degree of competition in the product market requiring investments in new products and processes (e.g. Schumpeter, 1942; Aghion, Harris, Howitt \& Vickers, 2001), technological and legal opportunities for appropriating returns (e.g. Teece, 1986) as well as providing technological opportunities (e.g. McGahan \& Silverman, 2006). Existing knowledge stocks (e.g. patents or employee skills) allow the firm to benefit from complementarities in their current R\&D investments (e.g. Cohen \& Levinthal, 1989; Dierickx \& Cool, 1989).
} 
(R\&D or other) only if the expected returns exceed the cost of capital based on a net present value rational. The pool of funds has three primary components:

Funds (Internal cash flows, equity finance, bank loans)

Most firms rely on internal cash flows for their R\&D projects (Kim, Mauer \& Sherman, 1998; Bond, Harhoff \& van Reenen, 1999; Haid \& Weigand, 2001; Harhoff, 1998). When it comes to external financing of innovations, venture capital financing has received a lot of attention in the literature (e.g. Gompers \& Lerner, 2001a; Bottazzi \& Da Rin, 2002; Audretsch \& Lehmann, 2004). It is generally acknowledged that access to venture capital is constrained for the majority of firms because of limited availability and the highly selective nature of venture capital investors who target a small number of investments with the potential for high returns (e.g. Eckhardt, Shane \& Delmar, 2006). Banks, however, as the primary provider of external financing for the vast majority of firms, appear ill-equipped to finance R\&D investments (Bozkaya \& Potterie, 2008).

Assuming a perfect market for capital, financing $R \& D$ investments should not be different from any other investment decision and firms should opt for all projects with a positive net present value (Modigliani \& Miller, 1958). However, the assumption does not hold because of the nature of R\&D (for recent reviews, see Hall, 2005 and Hall, 2009). The outcomes of R\&D are generally uncertain. This uncertainty has two primary dimensions (Amit et al., 1990). First, there is a substantial degree of technological uncertainty about the success of an R\&D project. Materials and procedures are almost by definition new and largely untested. Probability distributions for the success of an $R \& D$ project are difficult or even impossible to predict at the early stages (Hall, 2005). R\&D investments provide very little collateral. Half of all R\&D expenditures finance wages for skilled scientists and engineers (Hall, 2005). Investments in physical research assets and laboratories are often highly specific to a firm or even a project making it difficult to re-deploy, sell or use for others (Herrera \& Minetti, 2007). Secondly, there is a large degree of uncertainty about whether the firm will be economically successful with its technologically new products and processes. A significant proportion of product innovations end up as economic failures because they do not meet customer needs or because competitors are quick in their imitation or substitution activities, 
which erodes margins from the pioneering advantage (Dos Santos \& Peffers, 1995; Gourville, 2006).

Even so, research shows that these underlying uncertainties are not equally exogenous to managers and external capital providers. Endogenous uncertainty can be overcome by firm activities over time while exogenous uncertainties exist independently of any firm actions (Folta \& O'Brien, 2004; Cuypers \& Martin, 2009). Firms perform R\&D to resolve endogenous uncertainties through experimentation, testing and simulation. In that sense, R\&D is a sequential process in which firms uncover information and reduce endogenous uncertainty at each stage of the process (Roberts \& Weitzman, 1981). There is a long time span between the start of an $R \& D$ project and the appearance of revenues from it, i.e. when the uncertainty is ultimately resolved and success or failure is apparent to actors outside of the firm. Empirical estimates predict this time duration to be between four and five years albeit with significant differences across industry (e.g. Pakes \& Schankerman, 1984). Hence, firms have significant time advantages in discovering potentials or failures within $R \& D$ projects oder external partners, from whom the same uncertainties remain exogenous. This gives rise to an information asymmetry that insiders can exploit (Aboody \& Lev, 2000, Ahuja et al., 2005).

Banks are even more disadvantaged in this situation than equity investors because banks' have limited opportunities for directing/monitoring the use of their funds and they do not benefit from any resulting profits beyond the contractually fixed interest rate (Hennart, 1994). Moreover, in their lending decisions, all banks are equally subject to legal and regulatory constraints imposed by their institutional environment (e.g. Bank for International Settlement, 2005).

Financing R\&D investments is therefore characterized by a combination of information that is either unavailable (exogenous uncertainty) or asymmetrically distributed between the firm and its external capital providers (endogenous uncertainty). Appropriate risk premiums for individual borrowers cannot be assessed (Stiglitz, 2002) and firms find themselves creditconstrained because banks will only set high, average risk premiums (Aghion, Fally \& Scarpetta, 2007). As a result, the pool of funds available for $R \& D$ investment in a firm is deprived of bank financing. 
An emerging stream of literature from finance and strategic management is beginning to emphasize heterogeneities among banks and firm's signaling. The literature on banks and innovation financing is still scarce. Positive relations have been found for the development of the regional banking system (Benfratello et al., 2008) and relationship length (Herrera \& Minetti, 2007). Negative relationships stem from government ownership of banks (Sapienza, 2004; Haselmann, Katharina \& Weder di Mauro, 2009). Levitas et al. (2009) contribute to strategic management literature. They discern the value of signaling (through patents and distribution agreements) for overcoming financial constraints in small firms by attracting venture capital investors.

\section{$3 \quad$ Hypotheses development}

All of the theory presented so far rests on the important assumption that all banks draw from identical pools of information and should therefore suffer from identical degrees of information deficits. We question this assumption and argue that information is distributed asymmetrically between banks, too. We concede that the specific uncertainties related to R\&D investments of a particular firm are equally exogenous to all banks. However, information - on technological feasibility as well as market success - is produced by other firms in the same industry. At least parts of the uncertainties are therefore endogenous to these firms. We argue that banks are heterogeneous in their ability to access this information. What is more, we will set out the opportunities for the focal firm i to signal the value of its $\mathrm{R} \& \mathrm{D}$ activities and influence the availability of bank financing.

\subsection{Information externalities from a firm's main bank client portfolio}

Banks differ in their level of engagement with client firms. Boot et al. (2000) present a dichotomy of bank lending with varying levels in between. Transaction lending is closely related to brokerage activities where it is sufficient for the bank to lend based on a standardized transaction. Relationship lending, though, requires borrower-specific information for activities such as screening and monitoring (for a review see Boot, 2000). The relation specificity can provide banks with access to private data about the financed firm which can lead to a quasi-monopolistic banking position and superior benefits from future 
business with the particular client (Boot \& Thakor, 2000). We shall focus on a specific relationship, i.e. a firm's main bank, defined as the bank that a firm considers its primary source for all banking services. Within all relationship lending, main banks are uniquely positioned for acquisition of information about their client firms (Herrera \& Minetti, 2007).

We construct a simple theoretical model to investigate the effect of the client portfolio of a firm's main bank on the firm's R\&D investment which can be easily extended. We assume two identical firms $i_{s}$ and $j_{s}$. Both operate in industry s. Bank $A$ is the main bank of firm $i_{s}$, bank B is the main bank of firm $j_{s}$. Banks A and B are identical, except for their client portfolio. Each bank has only two firms in its portfolio. Bank A's portfolio consists of firm $i_{s}$ and identical firm $k_{s}$ which operates in the same industry; for short $\mathrm{P}_{\mathrm{A}}\left(\mathrm{i}_{\mathrm{s}}, \mathrm{k}_{\mathrm{s}}\right)$. It is further assumed that industry $s$ consists only of three firms $i_{s}$, $j_{s}$ and $k_{s}$. Bank B's portfolio encompasses firm $j_{s}$ and identical firm $l_{t}$ from a different industry $t$; in short $P_{B}\left(j_{s}, l_{t}\right)$.

We will develop a purely comparative argument for the R\&D investments of firms $i_{s}$ and $j_{s}$. We make the following assumptions: All firms have equal propensities to invest in R\&D. The underlying uncertainties and adverse selection problems for the particular R\&D investments are identical for bank A and B. They are fully exogenous to each bank. However, the portfolio composition can provide bank A with an information advantage over bank B. Firms can overcome endogenous uncertainties through various forms of $R \& D$, market research, prototyping, simulations, etc. All firms reveal information to their main banks through their transactions and loan applications. Substantial parts of this information can be expected to be private and not available to the general public. This information may include competitive interactions, future product and market plans as well as revenue streams (Boot \& Thakor, 2000). It is important to note that the private information is produced by the individual firm and only aggregated by its main bank which is uniquely positioned to do so. The bank does not necessarily learn in the narrow sense of exploring causal relationships but benefits from information externalities based on its client portfolio (Stiglitz, 2002). It is an externality because the bank does not directly and economically reimburse its other clients for the provision of this particular information. Hence, bank A and bank B draw from different pools of information in their lending decisions. The bank with the more relevant information can be expected to be in a position to assess risk premiums for individual firms more accurately than the general, high-risk premium. As a result, more funds will be available to its clients and, all 
other things being equal, the firm doing business with this bank should be able to make a comparatively greater investment in $\mathrm{R} \& \mathrm{D}$.

The relevance of the information externality of the main bank for firms $i_{s}$ and $j_{s}$ is greatest if the information stems from a similar technological and market context, i.e. from competitors in the same industry (Dussauge, Garrette \& Mitchell, 2000). Hence, $\mathrm{P}_{\mathrm{A}}\left(\mathrm{i}_{\mathrm{s}}, \mathrm{k}_{\mathrm{s}}\right)$ can be expected to deliver more relevant information externalities than $\mathrm{P}_{\mathrm{B}}\left(\mathrm{j}_{\mathrm{s}}, \mathrm{l}_{\mathrm{t}}\right)$ because bank $A$ can obtain information from firm $\mathrm{k}_{\mathrm{s}}$ which operates in the same industry as $\mathrm{i}_{\mathrm{s}}$. Given that the pool of relevant information is finite, i.e. from all firms in a given sector, a bank that has a greater number of such firms as its clients is more likely to benefit from information externalities. Hence, information asymmetries between bank A and bank B emerge from their market share with firms in sector s.

In a typical loan application process a bank will benchmark the information of a prospective borrower against key figures from its other clients in the same sector. This comparison is often times based on information stemming from other lending contracts which is not publicly available. The quality of such benchmarks is expected to be higher for banks that draw from a larger pool of industry information than banks with a comparatively narrower pool. In theory, firms could be expected to avoid certain banks in the first place because of the danger of unintentional knowledge spillovers to competitors. However, in reality, strong safeguards are in place to prevent banks from revealing information about one client to another client. The penalties would be high in terms of both legal liability and reputational losses (e.g. Degryse \& Ongena, 2001).

We propose:

Hypothesis 1: R\&D investment of a firm increases with the degree of market share of its main bank's corporate client portfolio in its industry.

However, the degree of specialization of its client portfolio is not an isolated information provision tool for the bank. A high degree of specialization in one industry would also imply that the risks involved from the technology or market side are highly correlated. This follows the basic rationale that banks manage the risks originating from their clients for the portfolio as a whole rather than individually (Markowitz, 1991). Banks can reduce the systemic risk of 
the overall portfolio by combining uncorrelated risks (Markowitz, 1952). Following this portfolio theory logic, $\mathrm{P}_{\mathrm{A}}\left(\mathrm{i}_{\mathrm{s}}, \mathrm{k}_{\mathrm{s}}\right)$ contains more risk than $\mathrm{P}_{\mathrm{B}}\left(\mathrm{j}_{\mathrm{s}}, \mathrm{l}_{\mathrm{t}}\right)$ because the risks originating from firms $j_{s}$ and $l_{t}$ can be expected to be less correlated since they operate in different sectors, i.e. market and technology environments, respectively. Bank A can be expected to demand a higher risk premium from its client $i_{s}$ than does bank $B$ from $j_{s}$ solely based soley on the risk exposure of its portfolio. As a result, available funds for $i_{s}$ should be comparatively lower, resulting in less $R \& D$ investment. We suggest:

Hypothesis 2: R\&D investment of a firm decreases with the degree of specialization of its main bank's corporate client portfolio in its industry.

Hypotheses 1 and 2 are not mutually exclusive. The former is denominated by the size of the industry the latter is dominated by the size of a bank's client portfolio. Banks with a small portfolio can easily have a portfolio which is dominated by clients from a single industry (i.e. high degree of specialization) while these clients represent only a small fraction of all firms in the industry (i.e. the bank has a small market share in the industry). The information externality logic suggests that banks benefit equally from every additional firm that they can take into their client portfolio. However, the aggregation of information from a bank's portfolio entails costs for the bank. These costs are especially high if the information is dispersed and, hence, difficult to screen (Koput, 1997). This effect is most pronounced if a bank is highly diversified across a large number of industries, i.e. the degree of portfolio specialization is low. Information screening becomes increasingly effective and efficient if fewer industry information domains have to be covered. Information processing at a bank can be expected to be especially productive if it draws from a large pool of information based on a large market share in a given industry and a high degree of specialization in this industry making the screening of the information more efficient. A bank with these characteristics should possess superior information for setting adequate risk premiums for its clients in that particular industry. This in turn, should enable these client firms to invest more in R\&D. We put forward:

Hypothesis 3: R\&D investment of a firm increases if its main bank has both a large market share in its industry and a high degree of 
specialization of its main bank's corporate client portfolio in its industry, i.e. there is a positive moderating effect.

Finally, the degree of uncertainty (both exogenous and endogenous) is not equally distributed across all industries. Especially at the "research" stage, which is not yet directed at a particular product, technological and market potentials are highly uncertain compared to the “development” stage, in which potential revenue streams are beginning to emerge (for a recent review, see Czarnitzki, Hottenrott \& Thorwarth, 2011). It can take several years between the start of an $R \& D$ project and the generation of economic returns (e.g. in pharmaceuticals) or just several months (e.g. in service sectors where production and consumption are almost instantaneous) (Berry, Shankar, Parish, Cadwallader \& Dotzel, 2006). Hence, the level of uncertainty of innovation activities in an industry is a function of the time it takes for an R\&D project to be ready for application. This distance to application has often been linked to the importance of scientific knowledge from universities which is closer to academic research and further removed from industrial commercialization (e.g. Siegel, Waldman, Atwater \& Link, 2004; Agrawal, 2006). Cohen, Nelson \& Walsh (2002) identify important differences among industries in the usage and importance of academic knowledge. We argue that the distance to application increases the uncertainty of the innovation activities in an industry. This, in turn, increases the potentials for benefitting from information asymmetries because the final resolution of fundamental uncertainties through observable market success is further removed in the future. At the same time, the risk of financing $R \& D$ increases if potential revenue streams are further delayed in the future (Czarnitzki et al., 2011).

We conclude:

Hypothesis 4: The positive effects of main bank industry market share and the negative effects of main bank industry specialization on firm $R \& D$ investment are greater in industries which rely heavily on knowledge from scientific sources.

\subsection{Signaling through reputation and legitimacy}

So far, we have considered mechanisms only on the bank side and their ability to overcome information asymmetries through externalities. However, firms have additional opportunities 
to overcome the information asymmetries by signaling the value of their $R \& D$ activities. We follow Ndofor et al. (2004) and define a signal as "conduct and observable attributes that alter the beliefs of, or convey information to, other individuals in the market about unobservable attributes and intentions (p.688)”. This is a deviation from the theory outlined in the previous section as firms $i_{s}$ and $j_{s}$ in the model are no longer considered to be identical. They differentiate themselves through firm-specific signaling. A credible signal will allow a bank to provide a more accurate risk assessment on a firm's $R \& D$ investment, resulting in more available funds and subsequently increased $R \& D$ investment. We will explore signals based on firms past actions (patenting) as well as legitimacy that can be transferred from ties to established actors and institutions (government R\&D subsidies and venture capital investors).

The value of signaling through past actions is rooted in theory of firm reputation (Rindova, Williamson, Petkova \& Sever, 2005). Levitas et al. (2009) investigates the value of patents as signals for attracting venture capital investors and corroborates it for a sample of firms from the pharmaceutical industry. Patents are a tangible representation of a successful innovation. Moreover, the patent office requires a certain degree of novelty in order to grant a patent (Encaoua, Guellec \& Martinez, 2006). The existence of a patent therefore also allows inferences to be drawn about the quality of the underlying $R \& D$. Patents can be interpreted as signals of future revenue streams. These may come from possessing a temporary advantage on the product market or through generating license fees (Levitas \& McFadyen, 2009). Hence, a main bank's risk concerns based on correlated risks in its client portfolio should be reduced.

Other potential signals are not rooted in a firm's past actions but in being associated with authoritative actors (Rindova et al., 2005). This perspective is rooted in institutional theory. Organizations can gain legitimacy and hence access to resources through external validation in establishing institutional linkages with established institutions or succeeding in contests (Baum \& Oliver, 1991; Rao, 1994). We focus predominantly on a firm's ability to attract external funds for R\&D or, more precisely, government R\&D subsidies and venture capital investment. Venture capital investors are known to be highly selective in their investment decisions (Eckhardt et al., 2006). They monitor firms intensely, conclude growth/performance-oriented contracts, facilitate crucial personnel decisions and provide additional services (e.g. access to strategic alliances) (e.g. Gompers \& Lerner, 2001b). As a result, the chances that the firm will be successful in the future and generate positive returns 
should increase. On the basis of this signal, banks should therefore be able to provide additional funds for the firm and its R\&D investment. Similarly, many governments provide $R \& D$ grants for firms to stimulate $R \& D$ investment. Information requirements in applications are extensive and competition for grants is intense (Czarnitzki \& Toole, 2007). Successful grant awards are highly selective and can signal the exceptional value of an R\&D project (Aerts \& Schmidt, 2008; Kleer, 2010). Banks may therefore rely on this external assessment for overcoming information asymmetries. We propose:

Hypothesis 5: A firm's R\&D investment increases with the degree of market share of its main bank's corporate client portfolio in its industry and this effect is reinforced by the patent stock of the focal firm, the presence of a venture capital investor or a government R\&D subsidy, i.e. there is a positive moderating effect.

Hypothesis 6: A firm's R\&D investment decreases with the degree of specialization of its main bank's corporate client portfolio in its industry, but this effect is mitigated by the firm's patent stock or if the focal firm has attracted a venture capital investor or received a government R\&D subsidy, i.e. there is a positive moderating effect.

\section{$4 \quad$ Empirical Study}

\subsection{Data}

We construct a unique panel dataset for testing the theoretical predictions. Data requirements are extensive because comprehensive information is required for banks and their client portfolio across multiple industries. What is more, the bank information needs to be linked to firm R\&D investment. We achieve this by linking multiple databases in Germany. The crucial starting point is the Mannheim Enterprise Panel (MUP).

This is a firm-level database collected by Creditreform, the leading credit rating agency in Germany. Since 1999, ZEW has been receiving a full copy of Creditreform's data-warehouse of firm level data and constructing the panel twice a year. Creditreform collects its data on the basis of regional firm registries. The Creditreform data cover nearly the entire population of 
3 million German firms with a few exceptions that are not legally required to register with the authorities (e.g. farmers). The Creditreform data are also the German input for the widely used AMADEUS database. Creditreform provides credit information and insurance services based on its data. Hence, the Creditreform data covers information that allows an assessment of a firm's credit worthiness. Most importantly for our study, it contains firms' bank relations, including the bank that firms consider as their main bank. Data quality can be considered to be high since keeping information on financial solvency and relationships up to dare is a core part of Creditreform's business model of and firms are not overly concerned about revealing their bank relationships (similar information can be found on a typical invoice). Given the population character of the database, we can calculate the industry composition of each bank's client portfolio. The bank information is very precise based on the German eight-digit bank code, which allows a precise identification of the banks' location and type (e.g. private bank vs. savings bank). Based on this information, we can track 2,432 banks. The banking code is mandatory for banks in Germany for obtaining a banking license. Coverage is therefore not limited. It should be acknowledged that the database does not contain information on the extent of each bank's lending engagement with individual firms. To the best of our knowledge, no such database is publicly available or accessible.

We link this dataset to the "Mannheim Innovation Panel” (MIP) which provides information on firm R\&D investment; the dependent variable of our analyses. The dataset is drawn as a representative, stratified random sample based on the German MUP firm population. In contrast to other studies analyzing bank-based financing for innovation we can therefore form perfect matches between the two databases, i.e. we do not have to rely on regional banking indicators (e.g. Benfratello et al., 2008) or statistical matching. The MIP survey is conducted annually by the Centre for European Economic Research (ZEW Mannheim) on behalf of the German Federal Ministry of Education and Research. For our study we use data from the 2002-06 surveys and analyze 7,294 firm observations from 4,363 firms. The panel is unbalanced.

The MIP survey targets $R \& D$ decision makers. These can be heads of $R \& D$ departments, innovation managers or CEOs, which is most likely the case in smaller firms where no elaborate functional structures exist. Several mechanisms are in place to secure the quality of the survey and its results. All core constructs in the survey follow the OECD's "Oslo Manual” on measuring innovation inputs, outputs and processes (OECD, 2005). Furthermore, the MIP 
is the German contribution to the Community Innovation Survey (CIS) of the European Union. CIS methodology and questionnaires have been refined over the years in international application. They are subject to extensive pre-testing and piloting in various countries, industries and firms with regard to interpretability, reliability and validity (Laursen \& Salter, 2006). This multinational application of CIS surveys guarantees quality management and assurance. CIS data have been the basis for several recent publications in highly ranked management journals (e.g. Laursen \& Salter, 2006; Leiponen \& Helfat, 2010).

The merged dataset contains precise identifiers for the European Patent Office statistics as well as the Bureau van Dijk ZEPHYR since it is also the basis for the AMADEUS database. The former linkage allows us to obtain the number of patents granted to each firm, the second one tracks venture capital investments. The final dataset contains 7,294 observations from 4,363 firms between 2002 and 2006 encompassing firm, innovation and R\&D characteristics, bank information, patent activity and venture capital investments.

\subsection{Empirical model}

\subsubsection{Dependent variable}

Our dependent variable is $R \& D$ investment measured as the share of $R \& D$ expenditures on total sales. This R\&D intensity measure is frequently used to take into account size effects (e.g. Cohen \& Levinthal, 1989).

\subsubsection{Independent variables}

We calculate for each firm the composition of the client portfolio of its main bank in its industry. We define the industry for this purpose at the two-digit NACE level for an aggregation that is neither too coarse nor too narrow, e.g. NACE34 covers firms in the automotive sector including OEMs and suppliers but not other transportation equipment. On the basis of this aggregation, a bank portfolio can be described along 84 different industry dimensions. We calculate the market share of a firm's main bank in an industry as the number of firms in the focal firm's industry in its client portfolio divided by all firms in this industry in Germany. This follows the basic rationale that all firms in an industry are the total pool of information from which a bank can potentially draw. We measure specialization as the 
percentage of firms in the focal firm's industry of the total portfolio of a firm's main bank portfolio. To account for differences in firm size we include the number of employees as weights in the calculations of the shares. This should be considered as a proxy in the absence of detailed bank lending information for all firms. Individual lending information for each bank and its clients would be preferable. However, after consulting with industry experts, we conclude that banks are highly unlikely to divulge such information owing to concerns about confidentiality and competition. The coefficients of the main bank market share and specialization variables test hypotheses 1 and 2 respectively. We test hypotheses 3 through a multiplicative interaction of both variables, i.e. whether the specialization of a bank's client portfolio in an industry where it has a large market share has an additional effect.

For the test of hypothesis 4 we construct a variable at the industry level capturing the use of scientific knowledge. Cohen et al. (2002) construct a similar variable based on the Carnegie Mellon innovation survey. We follow their approach and access the equivalent survey for Germany conducted in 2001, one year ahead of our observation period. The particular survey question asks heads of $R \& D$ departments about external knowledge sources that were important for their innovation activities during the preceding three years. Question layout and design are well established in strategic management research on firm's knowledge search (e.g. Laursen \& Salter, 2006; Leiponen \& Helfat, 2010). The survey is representative of the German firm population and we obtain projected values for how many firms in an industry used knowledge from universities and/or research institutes. We include the variable as a main effect in the model and split the sample into two sub-samples with above/below average use of scientific knowledge in the industry. Hypothesis 4 would be supported if the effects from a main bank's market share and specialization are stronger in the above average subsample.

Hypotheses 4 and 6 suggest effects from patenting, government R\&D subsidies and venture capital investment. We add the EPO patent stock for each firm to the model (scaled per employee) and a dummy variable for the presence of a venture capital investor. The MIP survey provides information on whether the firm has received a government R\&D subsidy at the European, federal or regional level. We include a dummy variable indicating whether this is the case or not. 
Our theoretical model predicts several relationships based on the "ceteris paribus" assumption. We add several control variables to ensure unbiased results. At the bank level we control for the type of bank. The structure of the German banking system is often described as the "Three Pillar System“ (see e.g. Krahnen \& Schmidt, 2004; Engerer \& Schrooten, 2004) and consists of municipality-owned savings banks (in German: “Sparkassen”), cooperative and private banks. All these banks are active as universal banks. However, there is evidence that private banks differ in their decision making from say government-owned banks (Sapienza, 2004; Porta, Lopez-de-Silanes \& Shleifer, 2002). Hence, we add a dummy variable indicating whether the firm's main bank is a savings or cooperative bank. Similarly, banks may differ in their size and regional orientation because investments have been found to be more likely in geographical proximity (Coval \& Moskowitz, 1999; Grinblatt \& Keloharju, 2001). We add control variables for the total client corporate portfolio of a firm's main bank (number of firms weighted by employees in logs) as well the share of client firms located in the same agglomeration area.

Firms may work with multiple banks which can in turn alter their relationship with the main bank (Boot \& Thakor, 2000; Ongena, Türmer-Alkan \& Westernhagen, 2007; Elsas 2005). Hence, we add the number of a firm's other banking contacts of a firm as a control variable to the model. Relationship length between a bank and its client has also been found to alter lending decisions (Herrera \& Minetti, 2007). The overwhelming majority of the firms in our sample (86\%) never change their main banking relationship during the five- year observation period. Hence, an exact measure of relationship length appears inappropriate. Conversely, we add a dummy variable indicating whether the firm has changed its main bank in the preceding three-year period. We proxy firm's internal cash flow through the return on sales from the previous year and its overall creditworthiness through its credit score. Creditreform determines the credit score as an index based on a proprietary formula which places heavy penalties on negative events such as delayed payments to suppliers or insolvency. All indices are standardized to ensure comparability. In addition, firms that are traded on the stock exchange have broader access to external financing. We control for this effect by adding a dummy variable for whether the firm is incorporated based on stock market shares.

Other factors may influence firm R\&D decisions. Firms can suffer from liabilities of size or newness in their resource acquisition (e.g. Shinkle \& Kriauciunas, 2009). We add firm size (number of employees in logs) and firm age (number of years since founding) to the model. 
Firms can also be part of a larger group and draw from its resources. Hence, we add a separate dummy variable for such cases. Finally, we capture remaining industry differences by including industry dummy variables. These follow grouped two-digit industry classes as suggested by OECD and Eurostat. The resulting groups are low-tech, medium low-tech, medium high-tech and high-tech manufacturing as well as low knowledge intensive and knowledge intensive services (see Appendix A for full details). Similarly, we add an additional control dummy for a firm's location in eastern Germany which, a result of reunification, has been found to provide geographical opportunities and challenges different from those in westen Germany as (e.g. Czarnitzki, 2005).

\subsubsection{Estimation model}

A logical inference from our theoretical reasoning is that some firms may not be able to invest in $R \& D$ at all, i.e. their $R \& D$ investment equals zero. Hence, a technique is required that takes into account that the dependent variable being censored at zero. We estimate censored panel regression models. In particular, we estimate random effects Tobit models. Fixed effects tobit models are only beginning to emerge and existing approaches have been criticized for delivering inconsistent estimates as well as being overly demanding on assumed data and variation (Cameron \& Trivedi, 2005; Grimpe \& Kaiser, 2010). The inconsistency stems primarily from the finite nature of empirical samples. Non-linear, fixed-effects models suffer especially from inconsistency issues because estimates are more likely to be influenced by incidental parameters (Heckman, 1987; Neyman \& Scott, 1948). Inconsistencies can be assumed to be reduced if the sample encompasses more than eight time periods, but random effects estimators are more commonly used (Cameron \& Trivedi, 2005). Given our data availabilities, we opt for a random effects model. We run several model specifications and include the independent variables of interest stepwise.

Insert Table 1 about here

We inspect the dataset for multicollinearity based on correlations and variance inflation factors and find no evidence by any conventionally applied standard (e.g. Chatterjee \& Hadi, 2006). The mean variance inflation factor equals 1.63 with the highest individual variance inflation factor equaling 3.94 (see Appendix B for full details). Table 1 provides descriptive 
statistics for the sample as well as a comprehensive overview of variable observation levels and scales.

\section{$5 \quad$ Results}

\subsection{Main bank specialization and market share}

Table 2 presents the estimation results of the tobit models testing hypotheses 1 and 2. Model 1 contains only control variables and can serve as a benchmark for all other models. Significant effects remain stable across models and the quality of model fit increases (log likelihood and Chi squared test).

\section{Insert Table 2 about here}

Model 2 includes the main effects of bank specialization and industry market share. A bank's market share in the focal firm's industry has a positive and highly significant effect on R\&D investment. Hence, hypothesis 1 is supported. The effect of bank specialization is negative and highly significant, lending support to hypothesis 2 . We calculate effect sizes based on a one standard derivation difference from the average in main bank industry specialization and market share. The former reduces firm R\&D intensity by $14 \%$, the latter increases it by $6 \%$. Hence, the effects are not just significantly different from zero but also have a sizeable impact on firm $R \& D$. This result reinforces the theoretical logic that both portfolio and information externality theory can inform predictions of firm R\&D investment through the main bank's client portfolio. Diversification in firms' main bank portfolio allows more firm $R \& D$ spending while the increasing industry specialization within a bank's portfolio allow less. We test a simultaneous relationship by adding a multiplicative interaction term between bank specialization and market share in model 3. Interestingly, there is no immediate relationship between the two variables beyond the main effects. As a result, neither mitigating nor reinforcing effects can be found and hypothesis 3 has to be rejected.

In hypothesis 4 we develop a theoretical argument for the effects to differing subject to the uncertainty in industry innovation activities depending on how far removed they are from application. The latter is proxied through the importance of scientific knowledge for 
innovation in an industry, which has a consistently positive and significant effect on firm $\mathrm{R} \& \mathrm{D}$ investment in Table 2 . We test hypothesis 4 by splitting the sample along the mean of the industry share of firms that use science as an input in their innovation activities. Table 3 shows the estimation results for both sub-samples. The negative effect of bank specialization remains significant in both samples. However, the significance level drops strongly in the subsample with industries that use less scientific knowledge. Conversely, the information externality effect appears to be confined to industries with an above-average use of scientific knowledge. Hence, hypothesis 4 is partially supported. Additionally, we test the significance of the multiplicative interaction effect between bank specialization and market share suggested in hypothesis 3 for the two sub-samples, too. There is no additional significant finding. Models are not reported.

Insert Table 3 about here

\subsection{Signaling effects}

We have developed hypotheses on three kinds of signals firms can send to their main banks: patents, government $R \& D$ subsidies and venture capital investments. The main effects of all of these factors are positive and significant. This is fully in line with existing research emphasizing complementarity effects of $R \& D$ with existing knowledge stocks embodied in patents (e.g. Cohen \& Levinthal, 1989) as well as additionality effects from government R\&D subsidies (e.g. Aerts \& Schmidt, 2008), and growth-oriented venture capital investments (e.g. Levitas \& McFadyen, 2009). However, the signaling effect that these factors may have on a firm's main bank is novel. We add separate multiplicative interaction effects with each factor and bank specialization in models 4, 5 and 6. We use separate models for each interaction to avoid potential issues arising from multicollinearity. Table 4 shows the results for these models.

Insert Table 4 about here

All main effects remain stable. Only the interaction effect between a firm's patent stock and its main bank's degree of portfolio specialization is positive and significant (Model 4). There are no additional significant interaction effects for firms having attracted a venture capital investor or having received a government R\&D subsidy (Model 5 and 6). All of the signals 
fail to alter the positive effects from information externalities of a bank's market share. In sum, hypothesis 5 is rejected. Hypothesis 6 is only supported for a firm's patent stock. Our result are in line with Levitas \& McFadyen (2009) who identify a similar positive patent effect for the venture capital market. In conclusion, the proposed signaling effects are limited to reputation effects based on the success of firms' past patenting success. Hence, the signaling effect is firm-specific and based on past innovation outcomes. Input-oriented signals originating from successfully attracting government R\&D subsidies or venture capital fail to alter the risk assessments or information position of banks. We suspect that this is due to the fact that they are general in nature and can be interpreted positively even without in-depth industry experience of a bank.

\subsection{Control variables}

All models contain an identical set of control variables. Their influence on firm $R \& D$ intensity is consistent across all models with regard to significance levels and directions. We have not developed theoretical predictions for any control variables but significant effects should be discussed briefly. First, it is noteworthy that out of all control variables at the bank level only the type of bank has a significant influence on firm R\&D investment. An average firm working with a savings or cooperative main bank invests significantly less in R\&D. This result supports other studies (Haselmann et al., 2009) which emphasize the inefficiencies in bank decision making induced by political influence through government ownership (Porta et al., 2002; Sapienza, 2004). R\&D intensity increases with firm size but decreases with firm age. Similarly, incorporated firms having access to the stock market invest more in R\&D. This provides evidence for the close relationship between overall resource availability for R\&D investments (Ahuja, Lampert \& Tandon, 2008) as well as R\&D as part of a growth strategy for young firms (King \& Levine, 1993). Similarly, the negative relationship between return on sales and $R \& D$ investment can be interpreted as an investment in generating the potential for future revenue streams in which the positive performance effects of current $R \& D$ are, on average, four to five years removed (Pakes \& Schankerman, 1984). The significant industry dummies (low tech manufacturing is the reference group) indicate that the $R \& D$ investment is a direct reflection of technological opportunities and competitive pressures. R\&D investment increases with the knowledge intensity of the industry in both manufacturing 
and services. Low knowledge-intensive service sectors such as transportation are the exception reflecting fewer technological opportunities (e.g. Lyons, Chatman \& Joyce, 2007).

\section{Consistency and sensitivity checks}

We estimate several additional empirical specifications to demonstrate the robustness of our findings. Appendix C shows the results. First, we investigate potential effects from the model choice. We replace the Tobit specification with an ordinary least squares regression in Model 4. The core findings on the effects of main bank market share and sector specialization remain intact. All other consistency check models are again based on the original Tobit model for comparison with the main model. Secondly, we follow up on the results of the control variables regarding significant differences for savings and cooperative banks. We have dedicated controls for bank size and geographic scope in every model. However, banks may also differ in their structure. Especially large private banks with a national branch system can benefit from accessing the knowledge pool/risk diversification of the group as a whole. We recalculate all portfolio variables at the group level and estimate separate models for savings and cooperative banks (Model 5) as well as private and national banks (Model 6). Our core findings remain stable in both groups indicating that the effects are not dependent on assumptions about the aggregation level of the banks or limited to certain bank types. Thirdly, our sample split in Table 3 shows that the impact of the positive effects originating from information externalities on firm R\&D investment are limited to sectors in which science is an important source of innovation. In an alternative operationalization, we capture the importance of science as a source of innovation based on the OECD classification for the R\&D intensity of certain sectors (Appendix A). Within this framework, sectors are classified based on the ratio of firms that perform R\&D continuously. Continuous R\&D activities imply that the value of knowledge production is long term and accumulative in certain sectors but rather transitory in others. We assume that the sectors with accumulative knowledge production are closer to the scientific knowledge production than other sectors and test it by splitting the sample based on the OECD classification. Model 7 shows the estimation results for low technology industries encompassing low-tech manufacturing as well as low knowledge-intensive services. Model 8 presents the equivalent estimation results for high-tech industries, which include medium- as well as high-tech manufacturing and knowledge- 
intensive services. The results support our main finding that the described effects in hypotheses 1 and 2 are largely confined to high-tech sectors. We can no longer identify the significant negative effect of main bank industry specialization on firm R\&D outside of science-based industries (Table 3) when compared with the low-tech industry classification in Model 8. Finally, our theoretical argument is strictly comparative in nature and combinations of firms and their main bank are assumed as given. This is largely in line with our descriptive statistics indicating that $85 \%$ of the firms in our sample never switch their main bank during the six year observation period. Nevertheless, firms and banks have made choices about this relationship at a certain point in time but this selection is unobservable to us. In order to test, whether the bank choice is correlated with the error term and may therefore bias the results, we estimate an additional instrument variable tobit model. The only bank choice variable available to us is whether the firm has changed its main bank in the preceding three years. We use this variable as the dependent variable in the first stage equation of the instrument variable estimation (Model 9). We rely on two regional variables (district level) as instruments. We argue that the economic development of a region provides firms as well as banks with more options. Hence, we use district GDP and then number of bank branches within a district (in logs) as instruments. The instruments are jointly significant at the $98 \%$ significance level; the number of bank branches is also individually significant. We conduct an additional Sargan test on potential overidentification which is rejected. Model 10 therefore contains the Tobit estimation results with the bank change being instrumented. Estimation results on our main hypothesis tests remain stable. In sum, we are confident that our empirical analyses provide reliable tests of our theoretical framework.

\section{$7 \quad$ Conclusions and Future Research}

In this study we question the general assumption that all banks suffer to the same degree from information deficits or asymmetries when providing funds for $R \& D$ intensive clients. We concede that banks cannot produce the necessary technological information themselves. They are, however, uniquely positioned to benefit from the information production of the firms in their client portfolio. Hence, they can benefit from an information externality which becomes important if the information is relevant to the technological and market environment of its clients, i.e. the bank has a large market share in the client's industry. We compare and 
contrast this effect with portfolio considerations and predict a negative relationship between a firm's R\&D investment and the industry specialization of its main bank. These theoretical predictions are supported by our empirical test for Germany based on a dataset that is, to our knowledge, unique in terms of variable coverage, representativeness, and comprehensiveness. The dataset also allows us to test whether the effects are equally pronounced in all industries. We find that the positive effect of information externalities is confined to high-tech industries in which academic research is a major source of knowledge. We have argued theoretically that this is due to increased uncertainties if innovation activities are further removed from commercial application. With regard to the signaling that the firm can provide itself about the quality of its $R \& D$, we find that only patents provide valuable signals to banks, and not government R\&D subsidies or venture capital investments. These findings have major implications for academic research as well as for practical management and policy development.

From an academic perspective, our contribution consists in connecting research in finance and strategic management. On the finance side, there has been angrowing interest recently in the financing of firm innovation and growth (Herrera \& Minetti, 2007; Benfratello et al., 2008), in which findings from current strategy literature have largely been absent. Conversely, strategic management literature has been heavily focused on venture capital investments (Levitas \& McFadyen, 2009) for firm innovation while largely ignoring the fact that these selective investments are dwarfed by the importance of bank financing for the vast majority of firms in most modern economies (Phelps \& Tilman, 2010). We see our theoretical combination of information externality and portfolio theory as a valuable extension of both research streams because it provides a novel, differentiated perspective on the largely acknowledged root cause of information availabilities and asymmetries. What is more, we identify both opportunities for and boundaries of firm signaling to important external partners such as banks. Especially the boundary conditions of ineffective signals are, to our knowledge, largely unexplored in the literature (e.g. Levitas \& McFadyen, 2009).

Our theoretical and empirical findings are strictly comparative in nature, and interpretations of opportunities for active search and selection (either through banks or firms) have to be made carefully. We find clear evidence that a firm's main bank makes a significant difference in the availability of funds for R\&D investment. Hence, it follows only logically that firms should be better off working with highly diversified banks. The positive effects of working 
with leading banks in a firm's industry are limited to sectors in which there are great underlying uncertainties. Interestingly, risk considerations stemming from specialization in a bank’s industry portfolio are a less pressing issue for firms with have opportunities to signal the value of their R\&D activities through patents. Venture capital investments or government R\&D subsidies are, in themselves, valuable for firms but provide no further signaling effect to a firm’s main bank.

On the policy making side, our results cast doubts on a general call for banks specializing in financing innovation. Banks with a broad industry portfolio are equally valuable because they can manage risks through diversification, especially for firms operating in more stable technological environments. What is more, we find that government $R \& D$ subsidies have value for firm R\&D investment itself, but their effect as a signaling tool to banks should not be overestimated. A similar logic applies to the potential signaling of venture capital investors.

In sum, our research provides a novel perspective on the relationship between banks, their information availabilities and the $R \& D$ investment of their firms. This provides fruitful avenues for future research. First, we develop and test strictly comparative arguments. This is partly due to the fact that the vast majority of the firms in our sample (85\%) never change their main bank. However, more detailed insights into how firms and banks select these relationships would be an important addition to our current model both theoretically and empirically. Secondly, we are able to investigate our research question empirically for a large economy with a well-established, diverse financial system. However, European economies have been described as being especially reliant on bank financing. Comparative studies in Anglo-American settings could provide valuable insights into the international generalizability of our findings. Thirdly, we have focused on the firm's R\&D input side. Banks may influence not just overall $R \& D$ investment but also the nature of firm $R \& D$ as well as the outcomes. We suspect that this particular research question lends itself more to qualitative research but we are confident that our comprehensive, quantitative analyses provides a reliable basis for it. 


\section{$8 \quad$ References}

Aboody, D. \& Lev, B. 2000. Information Asymmetry, R\&D, and Insider Gains. The Journal of Finance, 55 (6): 2747-2766.

Aerts, K. \& Schmidt, T. 2008. Two for the Price of One? On Additionality Effects of R\&D Subsidies: A Comparison between Flanders and Germany. Research Policy, 37 (5): 806-822.

Aghion, P., Fally, T. \& Scarpetta, S. 2007. Credit Constraints as a Barrier to the Entry and Post-Entry Growth of Firms. Economic Policy, 22 (52): 731-779.

Aghion, P., Harris, C., Howitt, P. \& Vickers, J. (2001), Competition, Imitation and Growth with Step-by-Step Innovation.

Agrawal, A. 2006. Engaging the Inventor: Exploring Licensing Strategies for University Inventions and the Role of Latent Knowledge. Strategic Management Journal, 27 (1): 63-79.

Ahuja, G., Coff, R.W. \& Lee, P.M. 2005. Managerial Foresight and Attempted Rent Appropriation: Insider Trading on Knowledge of Imminent Breakthroughs. Strategic Management Journal, 26 (9): 791-808.

Ahuja, G., Lampert, C.M. \& Tandon, V. 2008. Moving Beyond Schumpeter: Management Research on the Determinants of Technological Innovation. The Academy of Management Annals, 2: 1 - 98.

Amit, R., Glosten, L. \& Muller, E. 1990. Entrepreneurial Ability, Venture Investments, and Risk Sharing. Management Science, 36 (10): 1232-1245.

Audretsch, D.B. \& Lehmann, E.E. 2004. Financing High-Tech Growth: The Role of Banks and Venture Capitalists. Schmalenbach Business Review, 56: 340-357. 
Bank for International Settlement 2005. International Convergence of Capital Measurement and Capital Standards: A Revised Framework. Basel Committee on Banking Supervision: http://www.bis.org/publ/bcbs107.htm.

Baum, J.A.C. \& Oliver, C. 1991. Institutional Linkages and Organizational Mortality. Administrative Science Quarterly, 36 (2): 187-218.

Benfratello, L., Schiantarelli, F. \& Sembenelli, A. 2008. Banks and Innovation: Microeconometric Evidence on Italian Firms. Journal of Financial Economics, 90 (2): 197-217.

Berry, L.L., Shankar, V., Parish, J.T., Cadwallader, S. \& Dotzel, T. 2006. Creating New Markets through Service Innovation. MIT Sloan Management Review, 47 (2): 56-63.

Bond, S.R., Harhoff, D. \& van Reenen, J. (1999), Investment, R\&D and Financial Constraints in Britain and Germany.

Boot, A.W.A. 2000. Relationship Banking: What Do We Know? Journal of financial intermediation, 9 (1): 7-25.

Boot, A.W.A. \& Thakor, A.V. 2000. Can Relationship Banking Survive Competition? The Journal of Finance, 55 (2): 679-713.

Bottazzi, L. \& Da Rin, M. 2002. Venture Capital and the Financing of Innovative Firms. Economic Policy, 34: 229 - 269.

Bozkaya, A. \& Potterie, B. 2008. Who Funds Technology-Based Small Firms? Evidence from Belgium. Economics of Innovation and New Technology, 17 (1): 97-122.

Cameron, A. \& Trivedi, P. 2005. Microeconometrics: Methods and Applications. New York: Cambridge Univ Press. 
Chatterjee, S. \& Hadi, A.S. 2006. Regression Analysis by Example. New York: WileyInterscience.

Cohen, W.M. \& Levinthal, D.A. 1989. Innovation and Learning: The Two Faces of R\&D. The Economic Journal, 99: 569-596.

Cohen, W.M., Nelson, R.R. \& Walsh, J.P. 2002. Links and Impacts: The Influence of Public Research on Industrial R\&D. Management Science, 48 (1): 1-23.

Coval, J.D. \& Moskowitz, T.J. 1999. Home Bias at Home: Local Equity Preference in Domestic Portfolios. The Journal of Finance, 54 (6): 2045-2073.

Cuypers, I.R.P. \& Martin, X. 2009. What Makes and What Does Not Make a Real Option? A Study of Equity Shares in International Joint Ventures. Journal of International Business Studies, 41 (1): 47-69.

Czarnitzki, D. 2005. The Extent and Evolution of Productivity Deficiency in Eastern Germany. Journal of Productivity Analysis, 24 (2): 211-231.

Czarnitzki, D., Hottenrott, H. \& Thorwarth, S. 2011. Industrial Research Versus Development Investment: The Implications of Financial Constraints. Cambridge Journal of Economics, (forthcoming).

Czarnitzki, D. \& Toole, A.A. 2007. Business R\&D and the Interplay of R\&D Subsidies and Product Market Uncertainty. Review of Industrial Organization, 31 (3): 169-181.

Degryse, H. \& Ongena, S. 2001. Bank Relationships and Firm Profitability. Financial Management, 30 (1): 9-34.

Dierickx, I. \& Cool, K. 1989. Assett Stock Accumulation and Sustainability of Competitive Advantage. Management Science, 35 (12): 1504-1511. 
Dos Santos, B.L. \& Peffers, K. 1995. Rewards to Investors in Innovative Information Technology Applications: First Movers and Early Followers in Atms. Organization Science, 6 (3): 241-259.

Dussauge, P., Garrette, B. \& Mitchell, W. 2000. Learning from Competing Partners: Outcomes and Duration of Scale and Link Alliances in Europe, North America and Asia. Strategic Management Journal, 21 (2): 99-126.

Eckhardt, J.T., Shane, S. \& Delmar, F. 2006. Multistage Selection and the Financing of New Ventures. Management Science, 52 (2): 220-232.

Elsas, R. 2005 Empirical determinats of relationship lending. Journal of Financial Intermediation, 14: 32-57.

Encaoua, D., Guellec, D. \& Martinez, C. 2006. Patent Systems for Encouraging Innovation: Lessons from Economic Analysis. Research Policy, 35 (9): 1423-1440.

Engerer, H. \& Schrooten, M. 2004. Deutscher Bankensektor Im Umbruch - Sparkassen Und Genossenschaftsbanken Relativ Gut Positioniert. DIW Wochenbericht 71 (24): 345349.

Folta, T.B. \& O'Brien, J.P. 2004. Entry in the Presence of Dueling Options. Strategic Management Journal, 25 (2): 121-138.

Gompers, P. \& Lerner, J. 2001a. The Venture Capital Revolution. Journal of Economic Perspectives, 15: 145-168.

Gompers, P. \& Lerner, J. 2001b. The Venture Capital Revolution. Journal of Economic Perspectives, 15 (2): 145-168.

Gourville, J.T. 2006. Eager Sellers \& Stony Buyers. Harvard Business Review, 84 (6): 98106. 
Grant, R.M. 1996. Toward a Knowledge-Based Theory of the Firm. Strategic Management Journal, 17: 109-122.

Grimpe, C. \& Kaiser, U. 2010. Balancing Internal and External Knowledge Acquisition: The Gains and Pains from R\&D Outsourcing. Journal of Management Studies, 47 (8): 1483-1509.

Grinblatt, M. \& Keloharju, M. 2001. How Distance, Language, and Culture Influence Stockholdings and Trades. The Journal of Finance, 56 (3): 1053-1073.

Haid, A. \& Weigand, J. 2001. R\&D, Liquidity Constraints, and Corporate Governance. Jahrbücher für Nationalökonomie und Statistik, 221: 145-167.

Hall, B.H. 2005. The Financing of Innovation. In Shane, S. (ed.) The Handbook of Technology and Innovation Management: 409-430. Oxford: Blackwell.

Hall, B.H. 2009. The Financing of Innovative Firms. EIB Papers, 14 (2): 8-29.

Harhoff, D. 1998. Are There Financing Constraints for R\&D and Investment in German Manufacturing Firms? Annals d'Economie et de Statistique, 49/50: 421-456.

Haselmann, R., Katharina, M. \& Weder di Mauro, B. 2009. Real Effects of Bank Governance: Bank Ownership and Corporate Innovation. Centre for Economic Policy Research Discussion Paper no. 7488, London.

Heckman, J.J. 1987. The Incidental Parameters Problem and the Problem of Initial Conditions in Estimating a Discrete Time-Discrete Data Stochastic Process and Some Monte Carlo Evidence. In Manski, C. and D. McFadden (eds.), Structural Analysis of Discrete Data with Econometric Applications: 179-195. Cambridge, MA: MIT Press.

Hennart, J.-F. 1994. International Financial Capital Transfers: A Transaction Cost Framework. Business History, 36 (1): 51-70. 
Herrera, A.M. \& Minetti, R. 2007. Informed Finance and Technological Change: Evidence from Credit Relationships. Journal of Financial Economics, 83 (1): 223-269.

Kim, C., Mauer, D.C. \& Sherman, A.E. 1998. The Determinants of Corporate Liquidity: Theory and Evidence. Journal of Financial and Quantitative Analysis, 33: 335-359.

King, R.G. \& Levine, R. 1993. Finance, Entrepreneurship and Growth: Theory and Evidence. Journal of Monetary Economics, 32 (3): 513-542.

Kleer, R. 2010. Government R\&D Subsidies as a Signal for Private Investors. Research Policy, 39 (10): 1361-1374.

Koput, K.W. 1997. A Chaotic Model of Innovative Search: Some Answers, Many Questions. Organization Science, 8 (5): 528-542.

Krahnen, J.P. \& Schmidt, R.H. 2004. The German Financial System. Oxford, UK: Oxford University Press.

Laursen, K. \& Salter, A. 2006. Open for Innovation: The Role of Openness in Explaining Innovation Performance among U.K. Manufacturing Firms. Strategic Management Journal, 27 (2): 131-150.

Leiponen, A. \& Helfat, C.E. 2010. Innovation Opportunities, Knowledge Sources, and the Benefits of Breadth. Strategic Management Journal, 31 (2): 224-236.

Levitas, E. \& McFadyen, M.A. 2009. Managing Liquidity in Research-Intensive Firms: Signaling and Cash Flow Effects of Patents and Alliance Activities. Strategic Management Journal, 30 (6): 659-678.

Lyons, R.K., Chatman, J.A. \& Joyce, C.K. 2007. Innovation in Services: Corporate Culture and Investment Banking. California Management Review, 50 (1): 174-191.

Markowitz, H. 1952. Portfolio Selection. The Journal of Finance, 7 (1): 77-91. 
Markowitz, H.M. 1991. Foundations of Portfolio Theory. The Journal of Finance, 46 (2): 469-477.

McGahan, A.M. \& Silverman, B.S. 2006. Profiting from Technological Innovation by Others: The Effect of Competitor Patenting on Firm Value. Research Policy, 35 (8): 12221242.

Modigliani, F. \& Miller, M.H. 1958. The Cost of Capital, Corporation Finance and the Theory of Investment. The American Economic Review, 48 (3): 261-297.

Ndofor, H.A. \& Levitas, E. 2004. Signaling the Strategic Value of Knowledge. Journal of Management, 30 (5): 685-702.

Neyman, J. \& Scott, E.L. 1948. Consistent Estimates Based on Partially Consistent Observations. Econometrica, 16 (1): 1-32.

OECD 2005. Oslo Manual: Guidelines for Collecting and Interpreting Innovation Data. Paris: Organisation for Economic Co-operation and Development.

Ongena, S., Türmer-Alkan, G. \& von Westernhagen, N. 2007 Creditor concentration: an emirical investigation. Deutsche Bundesbank Discussion Paper Series 2: Banking and Financial Studies No 15/2007.

Pakes, A. \& Schankerman, M. 1984. The Rate of Obsolescence of Patents, Research Gestation Lags, and the Private Rate of Return of Research Resources. In Griliches, Z. (ed.) R\&D, Patents, and Productivity: 73-88. Chicago: University of Chicago Press.

Peutz, M., Meeus, M.T.H., Nooteboom, B. \& Noorderhaven, N.G. 2010. Financiering Van Innovatie in Mkb Zelf Aan Invoering Toe. Het Financieele Dagblad, September (8.09.2010).

Phelps, E.S. \& Tilman, L.M. 2010. Wanted: A First National Bank of Innovation. Harvard Business Review, 88 (1,2): 102-103. 
Porta, R.L., Lopez-de-Silanes, F. \& Shleifer, A. 2002. Government Ownership of Banks. The Journal of Finance, 57 (1): 265-301.

Rajan, R. \& Zingales, L. 2001. Financial Systems, Industrial Structure, and Growth. Oxford Review of Economic Policy, 17: 467-482.

Rao, H. 1994. The Social Construction of Reputation: Certification Contests, Legitimation, and the Survival of Organizations in the American Automobile Industry: 1895-1912. Strategic Management Journal, 15 (S1): 29-44.

Rindova, V.P., Williamson, I.O., Petkova, A.P. \& Sever, J.M. 2005. Being Good or Being Known: An Empirical Examination of the Dimensions, Antecedents, and Consequences of Organizational Reputation. Academy of Management Journal, 48 (6): 1033-1049.

Roberts, K. \& Weitzman, M.L. 1981. Funding Criteria for Research, Development, and Exploration Projects. Econometrica, 49 (5): 1261-1288.

Sapienza, P. 2004. The Effects of Government Ownership on Bank Lending. Journal of Financial Economics, 72 (2): 357-384.

Schumpeter, J.A. 1942. Capitalism, Socialism and Democracy. New York:

Shinkle, G.A. \& Kriauciunas, A.P. 2009. Institutions, Size and Age in Transition Economies: Implications for Export Growth. Journal of International Business Studies, 41 (2): 267-286.

Siegel, D.S., Waldman, D.A., Atwater, L.E. \& Link, A.N. 2004. Toward a Model of the Effective Transfer of Scientific Knowledge from Academicians to Practitioners: Qualitative Evidence from the Commercialization of University Technologies. Journal of Engineering and Technology Management, 21 (1-2): 115-142. 
Stiglitz, J.E. 2002. Information and the Change in the Paradigm in Economics. American Economic Review, 92 (3): 460-501.

Teece, D.J. 1986. Profiting from Technological Innovation: Implications for Integration, Collaboration, Licensing and Public Policy. Research Policy, 15 (6): 285-305.

\section{Tables}

Table 1: $\quad$ Descriptive statistics

\begin{tabular}{lllrrr} 
Variable & Level & Scale & Obs & Mean & Std. dev. \\
Share of R\&D expenditure in total sales & Firm & ratio & 7,294 & 0.03 & 0.09 \\
Bank sector specialization & Bank & continuous & 7,294 & 5.93 & 7.54 \\
Bank industry market share & Bank & continuous & 7,294 & 0.36 & 0.55 \\
Savings and cooperative banks & Bank & dummy & 7,294 & 0.50 & 0.50 \\
Bank size (in logs) & Bank & continuous & 7,294 & 10.33 & 1.28 \\
Bank geogr. scope & Bank & percentage & 7,294 & 66.59 & 34.74 \\
No of banks & Firm & continuous & 7,294 & 2.17 & 1.24 \\
Switch of bank relation & Firm & dummy & 7,294 & 0.15 & 0.36 \\
Return on sales (t-1) & Firm & stand. index & 7,294 & -0.03 & 0.99 \\
Patentstock per empl. & Firm & ratio & 7,294 & 0.00 & 0.01 \\
Company age since found. (years) & Firm & continuous & 7,294 & 17.02 & 14.17 \\
No of employees & Firm & continuous & 7,294 & 144.82 & 323.19 \\
Gov. R\&D subsidy & Firm & dummy & 7,294 & 0.16 & 0.36 \\
Credit rating & Firm & stand. index & 7,294 & -0.02 & 0.86 \\
Incorporated company on stocks & Firm & dummy & 7,294 & 0.03 & 0.18 \\
Venture capital investor & Firm & dummy & 7,294 & 0.00 & 0.07 \\
Part of company group & Firm & dummy & 7,294 & 0.38 & 0.49 \\
Location East Germany & Firm & dummy & 7,294 & 0.37 & 0.48 \\
Use of scientific knowledge & Industry & percentage & 7,294 & 50.98 & 13.29 \\
Medium-tech manuf. & Industry & dummy & 7,294 & 0.29 & 0.45 \\
High-tech manuf. & Industry & dummy & 7,294 & 0.08 & 0.28 \\
Low knowledge-intens. services & Industry & dummy & 7,294 & 0.15 & 0.35 \\
Knowledge-intens. services & Industry & dummy & 7,294 & 0.29 & 0.45 \\
\hline
\end{tabular}


Table 2: $\quad$ Estimation results of tobit models

\begin{tabular}{|c|c|c|c|}
\hline Variable & Model 1 & Model 2 & Model 3 \\
\hline Bank sector specialization & & $\begin{array}{c}-0.002^{* * * *} \\
(0.00)\end{array}$ & $\begin{array}{c}-0.002 * * * \\
(0.00)\end{array}$ \\
\hline Bank industry market share & & $\begin{array}{c}0.013^{* * *} \\
(0.00)\end{array}$ & $\begin{array}{c}0.013 * * \\
(0.01)\end{array}$ \\
\hline Int: Bank spec. * market share & & & $\begin{array}{l}0.000 \\
(0.00)\end{array}$ \\
\hline Savings and cooperative banks & $\begin{array}{c}-0.023^{* * *} \\
(0.01)\end{array}$ & $\begin{array}{c}-0.026^{* * *} \\
(0.01)\end{array}$ & $\begin{array}{c}-0.026 * * * \\
(0.01)\end{array}$ \\
\hline Bank size (in logs) & $\begin{array}{l}0.001 \\
(0.00)\end{array}$ & $\begin{array}{l}-0.003 \\
(0.00)\end{array}$ & $\begin{array}{l}-0.003 \\
(0.00)\end{array}$ \\
\hline Bank geogr. scope & $\begin{array}{l}0.000 \\
(0.00)\end{array}$ & $\begin{array}{l}0.000 \\
(0.00)\end{array}$ & $\begin{array}{l}0.000 \\
(0.00)\end{array}$ \\
\hline Switch of bank relation & $\begin{array}{l}0.007 \\
(0.01)\end{array}$ & $\begin{array}{l}0.006 \\
(0.01)\end{array}$ & $\begin{array}{l}0.006 \\
(0.01)\end{array}$ \\
\hline No of banks & $\begin{array}{l}-0.002 \\
(0.00)\end{array}$ & $\begin{array}{l}-0.001 \\
(0.00)\end{array}$ & $\begin{array}{l}-0.001 \\
(0.00)\end{array}$ \\
\hline Use of scientific knowledge & $\begin{array}{c}0.002 * * * \\
(0.00)\end{array}$ & $\begin{array}{c}0.002^{* * *} \\
(0.00)\end{array}$ & $\begin{array}{c}0.002^{* * *} \\
(0.00)\end{array}$ \\
\hline Return on sales & $\begin{array}{c}-0.003^{*} \\
(0.00)\end{array}$ & $\begin{array}{c}-0.004^{*} \\
(0.00)\end{array}$ & $\begin{array}{c}-0.004^{*} \\
(0.00)\end{array}$ \\
\hline Patentstock per empl. & $\begin{array}{c}1.864^{* * *} \\
(0.27)\end{array}$ & $\begin{array}{c}1.853^{* * *} \\
(0.27)\end{array}$ & $\begin{array}{c}1.853 * * * \\
(0.27)\end{array}$ \\
\hline No of employees & $\begin{array}{c}0.004^{* *} \\
(0.00)\end{array}$ & $\begin{array}{c}0.004^{* *} \\
(0.00)\end{array}$ & $\begin{array}{c}0.004^{* *} \\
(0.00)\end{array}$ \\
\hline Company age since found. (years) & $\begin{array}{c}-0.010^{* * *} \\
(0.00)\end{array}$ & $\begin{array}{c}-0.010^{* * *} \\
(0.00)\end{array}$ & $\begin{array}{c}-0.010 * * * \\
(0.00)\end{array}$ \\
\hline Gov. R\&D subsidy & $\begin{array}{c}0.103^{* * * *} \\
(0.00)\end{array}$ & $\begin{array}{c}0.103^{* * *} \\
(0.00)\end{array}$ & $\begin{array}{c}0.103^{* * *} \\
(0.00)\end{array}$ \\
\hline Credit rating & $\begin{array}{l}0.001 \\
(0.00)\end{array}$ & $\begin{array}{l}0.001 \\
(0.00)\end{array}$ & $\begin{array}{l}0.001 \\
(0.00)\end{array}$ \\
\hline Incorporated company on stocks & $\begin{array}{c}0.026^{* *} \\
(0.01)\end{array}$ & $\begin{array}{l}0.023^{*} \\
(0.01)\end{array}$ & $\begin{array}{l}0.023^{*} \\
(0.01)\end{array}$ \\
\hline Venture capital investor & $\begin{array}{c}0.129 * * * \\
(0.02)\end{array}$ & $\begin{array}{c}0.123^{* * *} \\
(0.02)\end{array}$ & $\begin{array}{c}0.123 * * * \\
(0.02)\end{array}$ \\
\hline Part of company group & $\begin{array}{l}0.000 \\
(0.00)\end{array}$ & $\begin{array}{r}-0.001 \\
(0.00)\end{array}$ & $\begin{array}{l}-0.001 \\
(0.00)\end{array}$ \\
\hline Location eastern Germany & $\begin{array}{l}-0.004 \\
(0.01)\end{array}$ & $\begin{array}{l}-0.005 \\
(0.01)\end{array}$ & $\begin{array}{l}-0.005 \\
(0.01)\end{array}$ \\
\hline Medium-tech manuf. & $\begin{array}{c}-0.015 \\
(0.01)\end{array}$ & $\begin{array}{l}-0.013 \\
(0.01)\end{array}$ & $\begin{array}{l}-0.012 \\
(0.01)\end{array}$ \\
\hline High-tech manuf. & $\begin{array}{c}0.032^{* * *} \\
(0.01)\end{array}$ & $\begin{array}{c}0.032^{* * *} \\
(0.01)\end{array}$ & $\begin{array}{c}0.032 * * * \\
(0.01)\end{array}$ \\
\hline Low knowledge-intens. services & $\begin{array}{c}-0.068^{* * *} \\
(0.01)\end{array}$ & $\begin{array}{c}-0.062^{* * *} \\
(0.01)\end{array}$ & $\begin{array}{c}-0.062 * * * \\
(0.01)\end{array}$ \\
\hline Knowledge-intens. services & $\begin{array}{l}0.006 \\
(0.01)\end{array}$ & $\begin{array}{c}0.019 * * \\
(0.01)\end{array}$ & $\begin{array}{c}0.019 * * \\
(0.01)\end{array}$ \\
\hline Year 2003 & $\begin{array}{c}-0.019 * * * \\
(0.01)\end{array}$ & $\begin{array}{c}-0.018^{* * *} \\
(0.01)\end{array}$ & $\begin{array}{c}-0.018 * * * \\
(0.01)\end{array}$ \\
\hline Year 2004 & $\begin{array}{r}-0.001 \\
(0.00)\end{array}$ & $\begin{array}{r}-0.001 \\
(0.00)\end{array}$ & $\begin{array}{r}-0.001 \\
(0.00)\end{array}$ \\
\hline Year 2005 & $0.029 * * *$ & $0.029 * * *$ & $0.029 * * *$ \\
\hline
\end{tabular}




\begin{tabular}{lccc}
\hline Variable & Model 1 & Model 2 & Model 3 \\
& $(0.01)$ & $(0.01)$ & $(0.01)$ \\
Year 2006 & -0.002 & -0.002 & -0.002 \\
& $(0.00)$ & $(0.00)$ & $(0.00)$ \\
Constant & $-0.193^{* * *}$ & $-0.145^{* * *}$ & $-0.146^{* * *}$ \\
& $(0.03)$ & $(0.03)$ & $(0.03)$ \\
sigma_u & $0.108^{* * *}$ & $0.107 * * *$ & $0.107^{* * *}$ \\
& $(0.00)$ & $(0.00)$ & $(0.00)$ \\
sigma_e & $0.077^{* * *}$ & $0.077^{* * *}$ & $0.077^{* * *}$ \\
& $(0.00)$ & $(0.00)$ & $(0.00)$ \\
Observations & 7294 & 7294 & 7294 \\
Number of IDs & 4363 & 4363 & 4363 \\
LR Chi2 & 1249.870 & 1288.900 & 1289.000 \\
log likelihood & 698.790 & 716.960 & 716.980 \\
\hline \multicolumn{3}{c}{} & $* \mathrm{c}<0.10, * * \mathrm{p}<0.05, * * * \mathrm{p}<0.01$
\end{tabular}


Table 3: $\quad$ Estimation results of tobit models with sub-samples of above/below average industry use of scientific knowledge

\begin{tabular}{|c|c|c|}
\hline Variable & $\begin{array}{l}\text { Industry with } \\
\text { below average } \\
\text { science use }\end{array}$ & $\begin{array}{c}\text { Industry with } \\
\text { above average } \\
\text { science use }\end{array}$ \\
\hline Bank sector specialization & $\begin{array}{c}-0.000 * \\
(0.00)\end{array}$ & $\begin{array}{c}-0.002 * * * \\
(0.00)\end{array}$ \\
\hline Bank industry market share & $\begin{array}{l}0.000 \\
(0.00)\end{array}$ & $\begin{array}{l}0.017^{* * *} \\
(0.01)\end{array}$ \\
\hline Savings and cooperative banks & $\begin{array}{l}0.000 \\
(0.00)\end{array}$ & $\begin{array}{c}-0.032^{* * *} \\
(0.01)\end{array}$ \\
\hline Bank size (in logs) & $\begin{array}{l}0.000 \\
(0.00)\end{array}$ & $\begin{array}{l}-0.010 \\
(0.00)\end{array}$ \\
\hline Bank geogr. scope & $\begin{array}{l}0.000 \\
(0.00)\end{array}$ & $\begin{array}{l}0.000 \\
(0.00)\end{array}$ \\
\hline Switch of bank relation & $\begin{array}{l}0.007 * * \\
(0.00)\end{array}$ & $\begin{array}{c}0.00 \\
(0.01)\end{array}$ \\
\hline No of banks & $\begin{array}{l}0.000 \\
(0.00)\end{array}$ & $\begin{array}{l}0.000 \\
(0.00)\end{array}$ \\
\hline Use of scientific knowledge & $\begin{array}{l}0.000 \\
(0.00)\end{array}$ & $\begin{array}{c}0.002^{* * *} \\
(0.00)\end{array}$ \\
\hline Return on sales & $\begin{array}{l}0.000 \\
(0.00)\end{array}$ & $\begin{array}{c}-0.006^{* *} \\
(0.00)\end{array}$ \\
\hline Patentstock per empl. & $\begin{array}{l}0.871^{* * *} \\
(0.32)\end{array}$ & $\begin{array}{c}1.847^{* * *} \\
(0.32)\end{array}$ \\
\hline No of employees & $\begin{array}{l}0.003^{* * *} \\
(0.00)\end{array}$ & $\begin{array}{l}0.005^{*} \\
(0.00)\end{array}$ \\
\hline Company age since found. (years) & $\begin{array}{c}-0.003^{*} \\
(0.00)\end{array}$ & $\begin{array}{c}-0.010 * * \\
(0.00)\end{array}$ \\
\hline Gov. $R \& D$ subsidy & $\begin{array}{l}0.046^{* * *} \\
(0.00)\end{array}$ & $\begin{array}{l}0.105^{* * *} \\
(0.01)\end{array}$ \\
\hline Credit rating & $\begin{array}{l}0.000 \\
(0.00)\end{array}$ & $\begin{array}{l}0.007^{*} \\
(0.00)\end{array}$ \\
\hline Incorporated company on stocks & $\begin{array}{l}-0.010 \\
(0.01)\end{array}$ & $\begin{array}{c}0.034^{* *} \\
(0.02)\end{array}$ \\
\hline Venture capital investor & $\begin{array}{c}0.039 * * \\
(0.02)\end{array}$ & $\begin{array}{l}0.138^{* * * *} \\
(0.03)\end{array}$ \\
\hline Part of company group & $\begin{array}{l}0.000 \\
(0.00)\end{array}$ & $\begin{array}{l}-0.010 \\
(0.01)\end{array}$ \\
\hline Location eastern Germany & $\begin{array}{c}-0.006^{*} \\
(0.00)\end{array}$ & $\begin{array}{l}0.000 \\
(0.01)\end{array}$ \\
\hline Medium-tech manuf. & $\begin{array}{l}0.018^{* * *} \\
(0.00)\end{array}$ & $\begin{array}{c}-0.056^{* * *} \\
(0.01)\end{array}$ \\
\hline High-tech manuf. & omitted & $\begin{array}{l}-0.01 \\
(0.01)\end{array}$ \\
\hline Low knowledge-intens. services & $\begin{array}{c}-0.020^{* * *} \\
(0.00)\end{array}$ & $\begin{array}{c}-0.144^{* * *} \\
(0.02)\end{array}$ \\
\hline Knowledge-intens. services & $\begin{array}{c}-0.020 * * * \\
(0.00)\end{array}$ & omitted \\
\hline Year 2003 & $\begin{array}{c}-0.008^{* *} \\
(0.00)\end{array}$ & $\begin{array}{c}-0.017^{* *} \\
(0.01)\end{array}$ \\
\hline Year 2004 & $\begin{array}{l}0.000 \\
(0.00)\end{array}$ & $\begin{array}{l}0.000 \\
(0.01)\end{array}$ \\
\hline Year 2005 & $0.007 * *$ & $0.036 * * *$ \\
\hline
\end{tabular}




\begin{tabular}{lcc}
\hline Variable & $\begin{array}{c}\text { Industry with } \\
\text { below average } \\
\text { science use }\end{array}$ & $\begin{array}{c}\text { Industry with } \\
\text { above average } \\
\text { science use } \\
(0.00)\end{array}$ \\
Year 2006 & $0.01)$ \\
& $(0.000$ & 0.000 \\
Constant & $-0.036^{* *}$ & $(0.01)$ \\
& $(0.02)$ & -0.09 \\
sigma_u & $0.040^{* * *}$ & $0.060^{* * *}$ \\
& $(0.00)$ & $(0.00)$ \\
sigma_e & $0.027^{* * *}$ & $0.086^{* * *}$ \\
& $(0.00)$ & $(0.00)$ \\
Observations & 3254 & 4040 \\
Number of IDs & 2033 & 2424 \\
LR Chi2 & 315.48 & 658.32 \\
log likelihood & 660.56 & 595.31 \\
\hline
\end{tabular}

${ }^{*} \mathrm{p}<0.10,{ }^{* *} \mathrm{p}<0.05,{ }^{* * *} \mathrm{p}<0.01$ 
Table 4: $\quad$ Estimation results of tobit models including interaction effects

\begin{tabular}{|c|c|c|c|}
\hline Variable & Model 4 & Model 5 & Model 6 \\
\hline Bank sector specialization & $\begin{array}{c}-0.002^{* * *} \\
(0.00)\end{array}$ & $\begin{array}{c}-0.002^{* * *} \\
(0.00)\end{array}$ & $\begin{array}{c}-0.002 * * * \\
(0.00)\end{array}$ \\
\hline Bank industry market share & $\begin{array}{c}0.012^{* *} \\
(0.00)\end{array}$ & $\begin{array}{c}0.013^{* * *} \\
(0.00)\end{array}$ & $\begin{array}{c}0.013^{* * *} \\
(0.00)\end{array}$ \\
\hline Savings and cooperative banks & $\begin{array}{c}-0.025^{* * *} \\
(0.01)\end{array}$ & $\begin{array}{c}-0.026^{* * *} \\
(0.01)\end{array}$ & $\begin{array}{c}-0.026 * * * \\
(0.01)\end{array}$ \\
\hline Int: Patents * bank sector spec. & $\begin{array}{c}0.002^{* *} \\
(0.00)\end{array}$ & & \\
\hline Int: Patents * bank market share & $\begin{array}{l}0.000 \\
(0.01)\end{array}$ & & \\
\hline Int: VC * bank sector spec. & & $\begin{array}{l}-0.012 \\
(0.01)\end{array}$ & \\
\hline Int: VC * bank market share & & $\begin{array}{l}0.002 \\
(0.07)\end{array}$ & \\
\hline Int: Gov. subs. * bank sector spec. & & & $\begin{array}{l}0.001 \\
(0.00)\end{array}$ \\
\hline Int: Gov. subs. * bank market share & & & $\begin{array}{l}-0.001 \\
(0.01)\end{array}$ \\
\hline Bank size (in logs) & $\begin{array}{l}-0.003 \\
(0.00)\end{array}$ & $\begin{array}{l}-0.003 \\
(0.00)\end{array}$ & $\begin{array}{l}-0.003 \\
(0.00)\end{array}$ \\
\hline Bank geogr. scope & $\begin{array}{l}0.000 \\
(0.00)\end{array}$ & $\begin{array}{l}0.000 \\
(0.00)\end{array}$ & $\begin{array}{l}0.000 \\
(0.00)\end{array}$ \\
\hline Switch of bank relation & $\begin{array}{l}0.006 \\
(0.01)\end{array}$ & $\begin{array}{l}0.007 \\
(0.01)\end{array}$ & $\begin{array}{l}0.007 \\
(0.01)\end{array}$ \\
\hline No of banks & $\begin{array}{l}-0.001 \\
(0.00)\end{array}$ & $\begin{array}{l}-0.001 \\
(0.00)\end{array}$ & $\begin{array}{l}-0.001 \\
(0.00)\end{array}$ \\
\hline Use of scientific knowledge & $\begin{array}{c}0.002^{* * *} \\
(0.00)\end{array}$ & $\begin{array}{c}0.002^{* * *} \\
(0.00)\end{array}$ & $\begin{array}{c}0.002^{* * *} \\
(0.00)\end{array}$ \\
\hline Return on sales & $\begin{array}{c}-0.004^{*} \\
(0.00)\end{array}$ & $\begin{array}{c}-0.003^{*} \\
(0.00)\end{array}$ & $\begin{array}{c}-0.004^{*} \\
(0.00)\end{array}$ \\
\hline Patentstock per empl. & $\begin{array}{c}1.677^{* * *} \\
(0.29)\end{array}$ & $\begin{array}{c}1.851^{* * *} \\
(0.27)\end{array}$ & $\begin{array}{c}1.861 * * * \\
(0.27)\end{array}$ \\
\hline No of employees & $\begin{array}{c}0.004^{* *} \\
(0.00)\end{array}$ & $\begin{array}{c}0.004^{* *} \\
(0.00)\end{array}$ & $\begin{array}{c}0.004^{* *} \\
(0.00)\end{array}$ \\
\hline Company age since found. (years) & $\begin{array}{c}-0.010^{* * *} \\
(0.00)\end{array}$ & $\begin{array}{c}-0.010 * * * \\
(0.00)\end{array}$ & $\begin{array}{c}-0.010 * * * \\
(0.00)\end{array}$ \\
\hline Gov. R\&D subsidy & $\begin{array}{c}0.103^{* * *} \\
(0.00)\end{array}$ & $\begin{array}{c}0.103^{* * *} \\
(0.00)\end{array}$ & $\begin{array}{c}0.099 * * * \\
(0.01)\end{array}$ \\
\hline Credit rating & $\begin{array}{l}0.001 \\
(0.00)\end{array}$ & $\begin{array}{l}0.001 \\
(0.00)\end{array}$ & $\begin{array}{l}0.001 \\
(0.00)\end{array}$ \\
\hline Incorporated company on stocks & $\begin{array}{l}0.022 * \\
(0.01)\end{array}$ & $\begin{array}{c}0.023^{* *} \\
(0.01)\end{array}$ & $\begin{array}{c}0.023 * * \\
(0.01)\end{array}$ \\
\hline Venture capital investor & $\begin{array}{c}0.123^{* * *} \\
(0.02)\end{array}$ & $\begin{array}{c}0.154^{* * *} \\
(0.04)\end{array}$ & $\begin{array}{c}0.123 * * * \\
(0.02)\end{array}$ \\
\hline Part of company group & $\begin{array}{l}-0.001 \\
(0.00)\end{array}$ & $\begin{array}{l}-0.001 \\
(0.00)\end{array}$ & $\begin{array}{l}-0.001 \\
(0.00)\end{array}$ \\
\hline Location eastern Germany & $\begin{array}{l}-0.005 \\
(0.01)\end{array}$ & $\begin{array}{l}-0.005 \\
(0.01)\end{array}$ & $\begin{array}{l}-0.005 \\
(0.01)\end{array}$ \\
\hline Medium-tech manuf. & $\begin{array}{l}-0.013 \\
(0.01)\end{array}$ & $\begin{array}{r}-0.012 \\
(0.01)\end{array}$ & $\begin{array}{l}-0.012 \\
(0.01)\end{array}$ \\
\hline High-tech manuf. & $0.032 * * *$ & $0.032 * * *$ & $0.033 * * *$ \\
\hline
\end{tabular}




\begin{tabular}{lccc}
\hline Variable & Model 4 & Model 5 & Model 6 \\
& $(0.01)$ & $(0.01)$ & $(0.01)$ \\
Low knowledge-intens. services & $-0.062^{* * *}$ & $-0.062^{* * *}$ & $-0.062^{* * *}$ \\
& $(0.01)$ & $(0.01)$ & $(0.01)$ \\
Knowledge-intens. services & $0.019^{* *}$ & $0.019^{* *}$ & $0.020^{* *}$ \\
& $(0.01)$ & $(0.01)$ & $(0.01)$ \\
Year 2003 & $-0.019^{* * *}$ & $-0.019^{* * *}$ & $-0.019^{* * *}$ \\
& $(0.01)$ & $(0.01)$ & $(0.01)$ \\
Year 2004 & -0.001 & -0.001 & -0.001 \\
& $(0.00)$ & $(0.00)$ & $(0.00)$ \\
Year 2005 & $0.028^{* * *}$ & $0.029^{* * *}$ & $0.028^{* * *}$ \\
& $(0.01)$ & $(0.01)$ & $(0.01)$ \\
Year 2006 & -0.002 & -0.002 & -0.002 \\
& $(0.00)$ & $(0.00)$ & $(0.00)$ \\
Constant & $-0.147^{* * *}$ & $-0.145^{* * *}$ & $-0.144^{* * *}$ \\
& $(0.03)$ & $(0.03)$ & $(0.03)$ \\
sigma_u & & & \\
& $0.107^{* * *}$ & $0.107^{* * *}$ & $0.107^{* * *}$ \\
sigma_e & $(0.00)$ & $(0.00)$ & $(0.00)$ \\
& & & \\
Observations & $0.077^{* * *}$ & $0.077^{* * *}$ & $0.077^{* * *}$ \\
Number of IDs & $(0.00)$ & $(0.00)$ & $(0.00)$ \\
LR Chi2 & 7294 & 7294 & 7294 \\
log likelihood & 4363 & 4363 & 4363 \\
& 1292.950 & 1292.080 & 1289.920 \\
& 719.320 & 717.990 & 717.840 \\
\hline & $*<0.10, * * \mathrm{p}<0.05, * * * \mathrm{p}<0.01$ &
\end{tabular}




\section{Appendix}

Appendix A: Construction of industry variables

\begin{tabular}{lll}
\hline Industry & NACE Code & Industry Group \\
Mining and quarrying & $10-14$ & Low-tech manufacturing \\
Food and tobacco & $15-16$ & Low-tech manufacturing \\
Textiles and leather & $17-19$ & Low-tech manufacturing \\
Wood / paper / publishing & $20-22$ & Low-tech manufacturing \\
Chemicals / petroleum & $23-24$ & Medium high-tech manufacturing \\
Plastic / rubber & 25 & Low-tech manufacturing \\
Glass / ceramics & 26 & Low-tech manufacturing \\
Metal & $27-28$ & Low-tech manufacturing \\
Manufacture of machinery and equipment & 29 & Medium tech manufacturing \\
Manufacture of electrical machinery & $30-32$ & High-tech manufacturing \\
Medical, precision and optical instruments & 33 & High-tech manufacturing \\
Manufacture of motor vehicles & $34-35$ & Medium tech manufacturing \\
Manufacture of furniture, jewellery, sports & $36-37$ & Low-tech manufacturing \\
equipment and toys & $40-41$ & Low-tech manufacturing \\
Electricity, gas and water supply & 45 & Low-tech manufacturing \\
Construction & 50,52 & Low knowledge-intensive services \\
Retail and motor trade & 51 & Low knowledge-intensive services \\
Wholesale trade & $60-63,64.1$ & Low knowledge-intensive services \\
Transportation and communication & $65-67$ & Knowledge-intensive services \\
Financial intermediation & $70-71$ & Distributive services \\
Real estate activities and renting & $72,64.3$ & Knowledge-intensive services \\
ICT services & $73,74.2,74.3$ & Knowledge-intensive services \\
Technical services & $74.1,74.4$ & Knowledge-intensive services \\
Consulting & $74.5-74.8,90$ & Low knowledge-intensive services \\
Low-tech business-oriented services & & \\
\hline
\end{tabular}


Appendix B: Correlation matrix and variance inflation factors

\begin{tabular}{|c|c|c|c|c|c|c|c|c|c|c|c|c|c|c|c|}
\hline & & (1) & (2) & (3) & (4) & (5) & (6) & (7) & (8) & (9) & $(10)$ & $(11)$ & (12) & (13) & (14) \\
\hline (1) & R\&D int. & 1.00 & & & & & & & & & & & & & \\
\hline (2) & $\begin{array}{l}\text { Bank sector } \\
\text { specialization }\end{array}$ & -0.06 & 1.00 & & & & & & & & & & & & \\
\hline (3) & $\begin{array}{l}\text { Bank industry } \\
\text { market share }\end{array}$ & 0.03 & 0.13 & 1.00 & & & & & & & & & & & \\
\hline (4) & $\begin{array}{l}\text { Savings and } \\
\text { cooperative banks }\end{array}$ & -0.08 & -0.08 & -0.35 & 1.00 & & & & & & & & & & \\
\hline (5) & Bank size (in logs) & 0.05 & -0.07 & 0.53 & -0.45 & 1.00 & & & & & & & & & \\
\hline (6) & Bank geogr. scope & -0.04 & 0.00 & -0.26 & 0.55 & -0.34 & 1.00 & & & & & & & & \\
\hline (7) & No of banks & 0.02 & -0.01 & 0.02 & -0.01 & 0.00 & -0.09 & 1.00 & & & & & & & \\
\hline (8) & $\begin{array}{l}\text { Switch of bank } \\
\text { relation }\end{array}$ & -0.09 & 0.01 & 0.07 & -0.06 & 0.01 & -0.02 & -0.01 & 1.00 & & & & & & \\
\hline (9) & Return on sales & 0.20 & -0.01 & 0.04 & -0.14 & 0.04 & -0.09 & 0.02 & -0.01 & 1.00 & & & & & \\
\hline (10) & $\begin{array}{l}\text { Patentstock per } \\
\text { empl. }\end{array}$ & -0.04 & -0.02 & 0.02 & 0.02 & 0.03 & 0.00 & -0.01 & -0.04 & 0.03 & 1.00 & & & & \\
\hline (11) & $\begin{array}{l}\text { Company age since } \\
\text { found. (years) }\end{array}$ & 0.15 & -0.03 & 0.02 & -0.03 & 0.03 & -0.04 & 0.00 & 0.08 & 0.13 & 0.05 & 1.00 & & & \\
\hline (12) & No of employees & -0.08 & 0.03 & 0.21 & -0.21 & 0.11 & -0.14 & 0.02 & 0.40 & 0.02 & -0.02 & 0.11 & 1.00 & & \\
\hline (13) & Gov. R\&D subsidy & -0.10 & 0.01 & 0.05 & -0.05 & 0.02 & -0.02 & -0.05 & 0.29 & -0.05 & -0.01 & 0.02 & 0.14 & 1.00 & \\
\hline (14) & Credit rating & 0.38 & -0.06 & 0.02 & -0.09 & 0.03 & -0.06 & 0.01 & -0.04 & 0.22 & -0.01 & 0.13 & 0.05 & -0.10 & 1.00 \\
\hline (15) & $\begin{array}{l}\text { Incorporated } \\
\text { company on stocks }\end{array}$ & 0.04 & 0.02 & -0.07 & 0.08 & -0.04 & 0.06 & -0.01 & -0.17 & -0.04 & -0.10 & -0.05 & -0.26 & -0.09 & -0.02 \\
\hline (16) & $\begin{array}{l}\text { Venture capital } \\
\text { investor }\end{array}$ & 0.06 & -0.03 & 0.04 & -0.02 & 0.05 & -0.02 & 0.01 & 0.09 & 0.05 & 0.01 & 0.08 & 0.13 & -0.13 & 0.08 \\
\hline (17) & $\begin{array}{l}\text { Part of company } \\
\text { group }\end{array}$ & 0.09 & -0.03 & -0.01 & -0.04 & 0.00 & 0.00 & -0.02 & 0.03 & 0.01 & -0.01 & 0.01 & 0.04 & -0.01 & 0.05 \\
\hline (18) & $\begin{array}{l}\text { Location eastern } \\
\text { Germany }\end{array}$ & 0.13 & -0.09 & 0.13 & -0.17 & 0.06 & -0.10 & 0.02 & 0.21 & 0.25 & 0.07 & 0.24 & 0.31 & 0.06 & 0.17 \\
\hline (19) & $\begin{array}{l}\text { Use of scientific } \\
\text { Knowl. }\end{array}$ & -0.02 & 0.00 & 0.15 & -0.18 & 0.09 & -0.14 & 0.05 & 0.12 & 0.05 & 0.01 & 0.08 & 0.42 & 0.03 & 0.03 \\
\hline (20) & $\begin{array}{l}\text { Medium-tech } \\
\text { manuf. }\end{array}$ & 0.11 & -0.07 & -0.08 & -0.14 & 0.00 & -0.12 & 0.04 & -0.23 & 0.00 & -0.05 & -0.06 & -0.16 & -0.22 & 0.13 \\
\hline (21) & High-tech manuf. & -0.04 & -0.13 & -0.01 & -0.09 & -0.03 & -0.07 & 0.01 & 0.15 & 0.47 & 0.01 & 0.08 & 0.20 & 0.06 & 0.07 \\
\hline (22) & $\begin{array}{l}\text { Low Knowl.- } \\
\text { intens. serv. }\end{array}$ & 0.18 & -0.14 & 0.06 & -0.07 & 0.05 & -0.05 & 0.00 & 0.01 & 0.30 & 0.07 & 0.13 & 0.05 & -0.01 & 0.21 \\
\hline (23) & $\begin{array}{l}\text { Knowl.-intens. } \\
\text { serv. }\end{array}$ & -0.12 & -0.01 & -0.03 & 0.06 & -0.03 & 0.03 & 0.01 & 0.01 & -0.17 & -0.06 & -0.07 & -0.04 & 0.04 & -0.12 \\
\hline (24) & $\begin{array}{l}\text { Knowl.-intens. } \\
\text { serv. }\end{array}$ & 0.13 & 0.33 & 0.00 & -0.02 & 0.08 & 0.03 & -0.01 & -0.22 & 0.04 & 0.03 & -0.05 & -0.23 & -0.14 & 0.01 \\
\hline (25) & Year 2003 & 0.00 & 0.01 & -0.02 & -0.01 & -0.02 & 0.00 & -0.01 & 0.01 & 0.01 & -0.01 & 0.00 & -0.01 & -0.01 & 0.07 \\
\hline (26) & Year 2004 & -0.02 & -0.02 & 0.00 & 0.01 & -0.01 & 0.00 & -0.01 & 0.01 & -0.02 & 0.01 & -0.01 & 0.02 & -0.03 & 0.02 \\
\hline (27) & Year 2005 & -0.01 & -0.02 & 0.00 & 0.00 & 0.01 & -0.01 & 0.01 & 0.01 & -0.01 & 0.00 & 0.02 & 0.01 & 0.04 & -0.20 \\
\hline \multirow[t]{2}{*}{ (28) } & Year 2006 & -0.01 & -0.01 & -0.01 & 0.03 & 0.00 & -0.01 & 0.03 & -0.02 & 0.01 & 0.00 & 0.01 & -0.03 & 0.08 & 0.02 \\
\hline & VIF & & 1.27 & 1.56 & 1.80 & 1.70 & 1.50 & 1.02 & 1.37 & 2.54 & 1.04 & 1.09 & 1.67 & 1.19 & 1.21 \\
\hline (15) & $\begin{array}{l}\text { Incorporated } \\
\text { company on stocks }\end{array}$ & 1.00 & & & & & & & & & & & & & \\
\hline (16) & $\begin{array}{l}\text { Venture capital } \\
\text { investor }\end{array}$ & -0.10 & 1.00 & & & & & & & & & & & & \\
\hline (17) & $\begin{array}{l}\text { Part of company } \\
\text { group }\end{array}$ & -0.02 & 0.07 & 1.00 & & & & & & & & & & & \\
\hline
\end{tabular}




\begin{tabular}{|c|c|c|c|c|c|c|c|c|c|c|c|c|c|c|c|}
\hline & & (1) & (2) & (3) & (4) & (5) & (6) & (7) & (8) & (9) & (10) & (11) & (12) & (13) & (14) \\
\hline (18) & $\begin{array}{l}\text { Location eastern } \\
\text { Germany }\end{array}$ & -0.11 & 0.08 & 0.07 & 1.00 & & & & & & & & & & \\
\hline (19) & $\begin{array}{l}\text { Use of scientific } \\
\text { Knowl. }\end{array}$ & -0.13 & 0.07 & 0.04 & 0.21 & 1.00 & & & & & & & & & \\
\hline (20) & $\begin{array}{l}\text { Medium-tech } \\
\text { manuf. }\end{array}$ & 0.07 & -0.04 & -0.01 & -0.17 & -0.10 & 1.00 & & & & & & & & \\
\hline (21) & High-tech manuf. & -0.08 & -0.02 & 0.00 & 0.30 & 0.08 & -0.05 & 1.00 & & & & & & & \\
\hline (22) & $\begin{array}{l}\text { Low Knowl.- } \\
\text { intens. serv. }\end{array}$ & -0.02 & 0.07 & 0.02 & 0.23 & 0.04 & 0.00 & -0.19 & 1.00 & & & & & & \\
\hline (23) & $\begin{array}{l}\text { Knowl.-intens. } \\
\text { serv. }\end{array}$ & -0.02 & -0.04 & -0.02 & -0.15 & -0.02 & -0.02 & -0.26 & -0.12 & 1.00 & & & & & \\
\hline (24) & $\begin{array}{l}\text { Knowl.-intens. } \\
\text { serv. }\end{array}$ & 0.10 & 0.03 & 0.01 & -0.26 & -0.08 & 0.08 & -0.40 & -0.19 & -0.26 & 1.00 & & & & \\
\hline (25) & Year 2003 & -0.03 & 0.01 & -0.01 & -0.02 & 0.04 & 0.02 & 0.00 & -0.01 & 0.02 & 0.01 & 1.00 & & & \\
\hline (26) & Year 2004 & 0.01 & 0.00 & -0.01 & 0.00 & 0.21 & -0.04 & 0.00 & -0.01 & 0.00 & -0.01 & -0.18 & 1.00 & & \\
\hline (27) & Year 2005 & -0.02 & -0.01 & 0.00 & 0.03 & -0.05 & 0.02 & 0.02 & -0.01 & -0.02 & -0.03 & -0.14 & -0.27 & 1.00 & \\
\hline \multirow[t]{2}{*}{ (28) } & Year 2006 & 0.01 & 0.00 & 0.02 & 0.01 & -0.12 & -0.01 & 0.00 & 0.01 & -0.01 & -0.02 & -0.20 & -0.37 & -0.29 & 1.00 \\
\hline & VIF & 1.11 & 1.08 & 1.02 & 1.43 & 1.34 & 1.22 & 3.98 & 2.39 & 1.77 & 3.02 & 1.35 & 1.80 & 1.66 & 1.82 \\
\hline
\end{tabular}

Appendix C: Consistency check estimation results

\begin{tabular}{|c|c|c|c|c|c|c|c|}
\hline Variable & $\begin{array}{c}\text { Model } 4 \\
\text { Full } \\
\text { sample } \\
\text { Regression }\end{array}$ & $\begin{array}{c}\text { Model } 5 \\
\text { Sub sample } \\
\text { Savings } \\
\text { and } \\
\text { cooperative } \\
\text { banks }\end{array}$ & $\begin{array}{l}\text { Model } 6 \\
\text { Sub } \\
\text { sample } \\
\text { Private } \\
\text { and } \\
\text { national } \\
\text { banks }\end{array}$ & $\begin{array}{c}\text { Model } 7 \\
\text { Sub } \\
\text { sample } \\
\text { Low tech } \\
\text { industries }\end{array}$ & $\begin{array}{c}\text { Model } 8 \\
\text { Sub } \\
\text { sample } \\
\text { High tech } \\
\text { industries }\end{array}$ & $\begin{array}{l}\text { Model } 9 \\
\text { Full } \\
\text { sample } \\
\text { IV 1st } \\
\text { stage - } \\
\text { Bank } \\
\text { switch }\end{array}$ & $\begin{array}{l}\text { Model } 10 \\
\text { Full } \\
\text { sample } \\
\text { IV 2nd } \\
\text { stage }\end{array}$ \\
\hline Bank sector specialization & $\begin{array}{c}-0.001^{* * *} \\
(0.00)\end{array}$ & $\begin{array}{c}-0.002^{* * *} \\
(0.00)\end{array}$ & $\begin{array}{c}-0.003^{* * *} \\
(0.00)\end{array}$ & $\begin{array}{l}0.000 \\
(0.00)\end{array}$ & $\begin{array}{c}-0.002^{* * *} \\
(0.00)\end{array}$ & $\begin{array}{l}0.000 \\
(0.00)\end{array}$ & $\begin{array}{c}-0.002 * * * \\
(0.00)\end{array}$ \\
\hline Bank industry market share & $\begin{array}{c}0.006^{* *} \\
(0.00)\end{array}$ & $\begin{array}{c}0.028^{* *} \\
(0.01)\end{array}$ & $\begin{array}{c}0.001^{* * * *} \\
(0.00)\end{array}$ & $\begin{array}{l}0.002 \\
(0.00)\end{array}$ & $\begin{array}{c}0.013 * * \\
(0.01)\end{array}$ & $\begin{array}{l}0.014 \\
(0.01)\end{array}$ & $\begin{array}{c}0.011^{* *} \\
(0.00)\end{array}$ \\
\hline Savings and cooperative banks & $\begin{array}{c}-0.010 * * * \\
(0.00)\end{array}$ & & & $\begin{array}{l}-0.004 \\
(0.00)\end{array}$ & $\begin{array}{c}-0.030^{* * *} \\
(0.01)\end{array}$ & $\begin{array}{c}0.043^{* * *} \\
(0.01)\end{array}$ & $\begin{array}{c}-0.030 * * * \\
(0.01)\end{array}$ \\
\hline Bank size (in logs) & $\begin{array}{l}-0.001 \\
(0.00)\end{array}$ & $\begin{array}{l}0.000 \\
(0.00)\end{array}$ & $\begin{array}{c}-0.009 * * * \\
(0.00)\end{array}$ & $\begin{array}{l}-0.001 \\
(0.00)\end{array}$ & $\begin{array}{l}-0.003 \\
(0.00)\end{array}$ & $\begin{array}{c}-0.008^{*} \\
(0.00)\end{array}$ & $\begin{array}{l}-0.003 \\
(0.00)\end{array}$ \\
\hline Bank geogr. scope & $\begin{array}{l}0.000 \\
(0.00)\end{array}$ & $\begin{array}{c}-0.000 * \\
(0.00)\end{array}$ & $\begin{array}{c}0.000 * * \\
(0.00)\end{array}$ & $\begin{array}{l}0.000 \\
(0.00)\end{array}$ & $\begin{array}{l}0.000 \\
(0.00)\end{array}$ & $\begin{array}{c}-0.001^{* * *} \\
(0.00)\end{array}$ & $\begin{array}{l}0.000 \\
(0.00)\end{array}$ \\
\hline Switch of bank relation & $\begin{array}{l}0.004 \\
(0.00)\end{array}$ & $\begin{array}{l}0.008 \\
(0.01)\end{array}$ & $\begin{array}{l}0.005 \\
(0.01)\end{array}$ & $\begin{array}{c}0.010^{* * *} \\
(0.00)\end{array}$ & $\begin{array}{l}0.003 \\
(0.01)\end{array}$ & & $\begin{array}{l}0.146 \\
(0.14)\end{array}$ \\
\hline No of banks & $\begin{array}{c}-0.001^{* *} \\
(0.00)\end{array}$ & $\begin{array}{l}0.000 \\
(0.00)\end{array}$ & $\begin{array}{l}-0.002 \\
(0.00)\end{array}$ & $\begin{array}{l}0.000 \\
(0.00)\end{array}$ & $\begin{array}{l}-0.002 \\
(0.00)\end{array}$ & $\begin{array}{l}0.000 \\
(0.00)\end{array}$ & $\begin{array}{l}0.000 \\
(0.00)\end{array}$ \\
\hline Use of scientific knowledge & $\begin{array}{c}0.001^{* * *} \\
(0.00)\end{array}$ & $\begin{array}{c}0.002^{* * *} \\
(0.00)\end{array}$ & $\begin{array}{c}0.002^{* * *} \\
(0.00)\end{array}$ & $\begin{array}{l}0.000 \\
(0.00)\end{array}$ & $\begin{array}{c}0.003^{* * *} \\
(0.00)\end{array}$ & $\begin{array}{l}0.001 \\
(0.00)\end{array}$ & $\begin{array}{c}0.002^{* * *} \\
(0.00)\end{array}$ \\
\hline Return on sales & $\begin{array}{c}-0.004^{* * *} \\
(0.00)\end{array}$ & $\begin{array}{l}-0.004 \\
(0.00)\end{array}$ & $\begin{array}{l}-0.004 \\
(0.00)\end{array}$ & $\begin{array}{l}0.001 \\
(0.00)\end{array}$ & $\begin{array}{c}-0.005^{* *} \\
(0.00)\end{array}$ & $\begin{array}{l}-0.003 \\
(0.00)\end{array}$ & $\begin{array}{c}-0.004^{*} \\
(0.00)\end{array}$ \\
\hline Patentstock per empl. & $\begin{array}{c}1.332^{* * *} \\
(0.30)\end{array}$ & $\begin{array}{c}1.442^{* * *} \\
(0.39)\end{array}$ & $\begin{array}{c}2.028 * * * \\
(0.37)\end{array}$ & $\begin{array}{c}0.962^{* * *} \\
(0.36)\end{array}$ & $\begin{array}{c}1.885^{* * *} \\
(0.31)\end{array}$ & $\begin{array}{l}-0.180 \\
(0.62)\end{array}$ & $\begin{array}{c}1.945^{* * *} \\
(0.26)\end{array}$ \\
\hline No of employees & $\begin{array}{c}-0.004 * * * \\
(0.00)\end{array}$ & $\begin{array}{l}0.003 \\
(0.00)\end{array}$ & $\begin{array}{c}0.005^{* *} \\
(0.00)\end{array}$ & $\begin{array}{c}0.003^{* *} \\
(0.00)\end{array}$ & $\begin{array}{l}0.003 \\
(0.00)\end{array}$ & $\begin{array}{l}0.003 \\
(0.00)\end{array}$ & $\begin{array}{l}0.002 \\
(0.00)\end{array}$ \\
\hline Company age since found. (years) & $\begin{array}{c}-0.003^{* *} \\
(0.00)\end{array}$ & $\begin{array}{c}-0.010 * * \\
(0.00)\end{array}$ & $\begin{array}{c}-0.009 * * \\
(0.00)\end{array}$ & $\begin{array}{c}-0.003^{*} \\
(0.00)\end{array}$ & $\begin{array}{c}-0.010^{* * *} \\
(0.00)\end{array}$ & $\begin{array}{c}-0.020 * * * \\
(0.01)\end{array}$ & $\begin{array}{c}-0.007^{*} \\
(0.00)\end{array}$ \\
\hline
\end{tabular}




\begin{tabular}{|c|c|c|c|c|c|c|c|}
\hline Gov. R\&D subsidy & $\begin{array}{c}0.077 * * * \\
(0.01)\end{array}$ & $\begin{array}{c}0.096^{* * * *} \\
(0.01)\end{array}$ & $\begin{array}{c}0.104^{* * *} \\
(0.01)\end{array}$ & $\begin{array}{c}0.044 * * * \\
(0.00)\end{array}$ & $\begin{array}{c}0.108 * * * \\
(0.01)\end{array}$ & $\begin{array}{l}0.009 \\
(0.01)\end{array}$ & $\begin{array}{c}0.153^{* * *} \\
(0.01)\end{array}$ \\
\hline Credit rating & $\begin{array}{l}0.002 \\
(0.00)\end{array}$ & $\begin{array}{l}0.000 \\
(0.00)\end{array}$ & $\begin{array}{l}0.003 \\
(0.00)\end{array}$ & $\begin{array}{l}-0.001 \\
(0.00)\end{array}$ & $\begin{array}{l}0.004 \\
(0.00)\end{array}$ & $\begin{array}{l}-0.001 \\
(0.01)\end{array}$ & $\begin{array}{l}0.001 \\
(0.00)\end{array}$ \\
\hline Incorporated company on stocks & $\begin{array}{l}0.011 \\
(0.01)\end{array}$ & $\begin{array}{c}0.046^{* * *} \\
(0.02)\end{array}$ & $\begin{array}{l}0.001 \\
(0.02)\end{array}$ & $\begin{array}{l}-0.012 \\
(0.01)\end{array}$ & $\begin{array}{c}0.038 * * * \\
(0.01)\end{array}$ & $\begin{array}{l}-0.008 \\
(0.02)\end{array}$ & $\begin{array}{l}0.015 \\
(0.01)\end{array}$ \\
\hline Venture capital investor & $\begin{array}{l}0.083^{*} \\
(0.05)\end{array}$ & $\begin{array}{l}0.064 \\
(0.05)\end{array}$ & $\begin{array}{c}0.133^{* * * *} \\
(0.03)\end{array}$ & $\begin{array}{l}0.033 \\
(0.02)\end{array}$ & $\begin{array}{c}0.135^{* * *} \\
(0.03)\end{array}$ & $\begin{array}{l}-0.094 \\
(0.06)\end{array}$ & $\begin{array}{c}0.125 * * * \\
(0.03)\end{array}$ \\
\hline Part of company group & $\begin{array}{l}-0.002 \\
(0.00)\end{array}$ & $\begin{array}{l}0.002 \\
(0.01)\end{array}$ & $\begin{array}{l}-0.004 \\
(0.01)\end{array}$ & $\begin{array}{l}0.004 \\
(0.00)\end{array}$ & $\begin{array}{l}-0.003 \\
(0.01)\end{array}$ & $\begin{array}{c}0.035^{* * *} \\
(0.01)\end{array}$ & $\begin{array}{l}0.002 \\
(0.01)\end{array}$ \\
\hline Location eastern Germany & $\begin{array}{l}0.004 \\
(0.00)\end{array}$ & $\begin{array}{l}-0.009 \\
(0.01)\end{array}$ & $\begin{array}{l}-0.001 \\
(0.01)\end{array}$ & $\begin{array}{l}-0.005 \\
(0.00)\end{array}$ & $\begin{array}{l}-0.005 \\
(0.01)\end{array}$ & $\begin{array}{c}0.027 * * * \\
(0.01)\end{array}$ & $\begin{array}{c}-0.013^{* *} \\
(0.01)\end{array}$ \\
\hline Medium-tech manuf. & $\begin{array}{c}-0.015^{* * *} \\
(0.00)\end{array}$ & $\begin{array}{l}-0.007 \\
(0.01)\end{array}$ & $\begin{array}{l}-0.017 \\
(0.01)\end{array}$ & & & $\begin{array}{l}-0.015 \\
(0.02)\end{array}$ & $\begin{array}{l}-0.005 \\
(0.01)\end{array}$ \\
\hline High-tech manuf. & $\begin{array}{c}0.018^{* * *} \\
(0.01)\end{array}$ & $\begin{array}{l}0.027 * \\
(0.01)\end{array}$ & $\begin{array}{l}0.030 * \\
(0.02)\end{array}$ & & $\begin{array}{c}0.043^{* * *} \\
(0.01)\end{array}$ & $\begin{array}{l}-0.025 \\
(0.02)\end{array}$ & $\begin{array}{c}0.042^{* * *} \\
(0.01)\end{array}$ \\
\hline Low knowledge-intens. services & $\begin{array}{c}-0.010^{* * *} \\
(0.00)\end{array}$ & $\begin{array}{c}-0.065^{* * *} \\
(0.01)\end{array}$ & $\begin{array}{c}-0.054^{* * *} \\
(0.01)\end{array}$ & $\begin{array}{c}-0.019 * * * \\
(0.00)\end{array}$ & & $\begin{array}{l}0.008 \\
(0.02)\end{array}$ & $\begin{array}{c}-0.063^{* * *} \\
(0.01)\end{array}$ \\
\hline Knowledge-intens. services & $\begin{array}{c}0.019 * * * \\
(0.00)\end{array}$ & $\begin{array}{l}0.013 \\
(0.01)\end{array}$ & $\begin{array}{c}0.041^{* * * *} \\
(0.01)\end{array}$ & & $\begin{array}{c}0.032^{* * *} \\
(0.01)\end{array}$ & $\begin{array}{l}-0.003 \\
(0.02)\end{array}$ & $\begin{array}{c}0.024^{* * *} \\
(0.01)\end{array}$ \\
\hline Year 2003 & $\begin{array}{c}-0.008^{* * *} \\
(0.00)\end{array}$ & $\begin{array}{c}-0.024^{* * *} \\
(0.01)\end{array}$ & $\begin{array}{c}-0.020^{* * *} \\
(0.01)\end{array}$ & $\begin{array}{l}-0.008 \\
(0.00)\end{array}$ & $\begin{array}{c}-0.019 * * * \\
(0.01)\end{array}$ & $\begin{array}{l}0.014 \\
(0.02)\end{array}$ & $\begin{array}{c}-0.022^{* *} \\
(0.01)\end{array}$ \\
\hline Year 2004 & $\begin{array}{c}-0.005 * \\
(0.00)\end{array}$ & $\begin{array}{l}0.002 \\
(0.01)\end{array}$ & $\begin{array}{l}-0.008 \\
(0.01)\end{array}$ & $\begin{array}{c}0.009 * * \\
(0.00)\end{array}$ & $\begin{array}{l}-0.006 \\
(0.01)\end{array}$ & $\begin{array}{l}0.014 \\
(0.01)\end{array}$ & $\begin{array}{l}-0.005 \\
(0.01)\end{array}$ \\
\hline Year 2005 & $\begin{array}{c}0.009 * * * \\
(0.00)\end{array}$ & $\begin{array}{c}0.023^{* * *} \\
(0.01)\end{array}$ & $\begin{array}{c}0.028 * * * \\
(0.01)\end{array}$ & $\begin{array}{c}0.011^{* * * *} \\
(0.00)\end{array}$ & $\begin{array}{c}0.033^{* * *} \\
(0.01)\end{array}$ & $\begin{array}{c}0.042^{* * *} \\
(0.01)\end{array}$ & $\begin{array}{c}0.033^{* * *} \\
(0.01)\end{array}$ \\
\hline Year 2006 & $\begin{array}{l}-0.003 \\
(0.00)\end{array}$ & $\begin{array}{l}-0.008 \\
(0.01)\end{array}$ & $\begin{array}{l}0.000 \\
(0.01)\end{array}$ & $\begin{array}{l}0.002 \\
(0.00)\end{array}$ & $\begin{array}{l}-0.003 \\
(0.01)\end{array}$ & $\begin{array}{c}0.050^{* * *} \\
(0.01)\end{array}$ & $\begin{array}{l}-0.005 \\
(0.01)\end{array}$ \\
\hline Bank branches in district (logs) & & & & & & $\begin{array}{c}0.021^{* * *} \\
(0.01)\end{array}$ & \\
\hline GDP in district & & & & & & $\begin{array}{l}0.000 \\
(0.00)\end{array}$ & \\
\hline Constant & $\begin{array}{l}0.017 \\
(0.01)\end{array}$ & $\begin{array}{c}-0.157^{* * *} \\
(0.04)\end{array}$ & $\begin{array}{c}-0.074^{*} \\
(0.04)\end{array}$ & $\begin{array}{c}-0.035^{*} \\
(0.02)\end{array}$ & $\begin{array}{c}-0.206^{* * *} \\
(0.04)\end{array}$ & $\begin{array}{c}0.174^{* * *} \\
(0.06)\end{array}$ & $\begin{array}{c}-0.161^{* * *} \\
(0.05)\end{array}$ \\
\hline sigma_u & & $\begin{array}{c}0.099 * * * \\
(0.00)\end{array}$ & $\begin{array}{c}0.114^{* * *} \\
(0.00)\end{array}$ & $\begin{array}{c}0.040^{* * * *} \\
(0.00)\end{array}$ & $\begin{array}{c}0.118^{* * * *} \\
(0.00)\end{array}$ & & \\
\hline sigma_e & & $\begin{array}{c}0.076^{* * * *} \\
(0.00)\end{array}$ & $\begin{array}{c}0.073^{* * *} \\
(0.00)\end{array}$ & $\begin{array}{c}0.028^{* * * *} \\
(0.00)\end{array}$ & $\begin{array}{c}0.083^{* * *} \\
(0.00)\end{array}$ & & \\
\hline Observations & 7294 & 3676 & 3618 & 2503 & 4791 & 7294 & 7294 \\
\hline Number of IDs & 4363 & 2262 & 2154 & 1571 & 2865 & 4363 & 4363 \\
\hline F-test/LR Chi2 & 22.94 & 555.83 & 731.25 & 188.84 & 795.30 & 5.83 & 1874.33 \\
\hline log likelihood & 8286.92 & 181.69 & 584.38 & 444.40 & 618.66 & -2704.13 & 21888.10 \\
\hline
\end{tabular}

